Article

\title{
Anticancer Activity of Half-Sandwich Ru, Rh and Ir Complexes with Chrysin Derived Ligands: Strong Effect of the Side Chain in the Ligand and Influence of the Metal
}

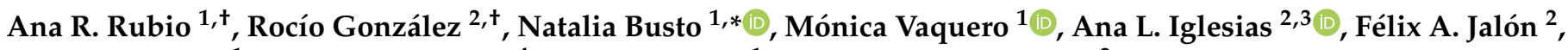 \\ Gustavo Espino ${ }^{1}$, Ana M. Rodríguez ${ }^{4}$, Begoña García ${ }^{1}$ and Blanca R. Manzano ${ }^{2, *}$ \\ 1 Departamento de Química, Facultad de Ciencias, Universidad de Burgos, Plaza Misael Bañuelos s/n, \\ 09001 Burgos, Spain; ana.rosa.rubio.antolin@gmail.com (A.R.R.); mvaquero@ubu.es (M.V.); \\ gespino@ubu.es (G.E.); begar@ubu.es (B.G.) \\ 2 Facultad de Ciencias y Tecnologías Químicas-IRICA, Universidad de Castilla-La Mancha, Avda. C. J. Cela 10, \\ 13071 Ciudad Real, Spain; dra.gonzalez.alvarez@gmail.com (R.G.); aiglesias@uabc.edu.mx (A.L.I.); \\ Felix.Jalon@uclm.es (F.A.J.) \\ 3 Facultad de Ciencias de la Ingeniería y Tecnología (FCITEC), Universidad Autónoma de Baja California, Blvd. \\ Universitario \# 1000, Unidad Valle de las Palmas, Baja California, Tijuana 21500, Mexico \\ 4 Departamento de Química Inorgánica, Orgánica y Bioquímica, Escuela Técnica Superior de Ingenieros \\ Industriales, Universidad de Castilla-La Mancha, Avda. C. J. Cela 2, 13071 Ciudad Real, Spain; \\ AnaMaria.RFdez@uclm.es \\ check for \\ updates \\ Citation: Rubio, A.R.; González, R.; \\ * Correspondence: nbusto@ubu.es (N.B.); blanca.manzano@uclm.es (B.R.M.) \\ + These authors contributed equally to this work.
} Busto, N.; Vaquero, M.; Iglesias, A.L.; Jalón, F.A.; Espino, G.; Rodríguez, A.M.; García, B.; Manzano, B.R. Anticancer Activity of Half-Sandwich $\mathrm{Ru}, \mathrm{Rh}$ and Ir Complexes with Chrysin Derived Ligands: Strong Effect of the Side Chain in the Ligand and Influence of the Metal. Pharmaceutics 2021, 13, 1540. https://doi.org/10.3390/ pharmaceutics13101540

Academic Editors: Francesco Grossi and Haibing Zhou

Received: 31 July 2021

Accepted: 17 September 2021

Published: 23 September 2021

Publisher's Note: MDPI stays neutral with regard to jurisdictional claims in published maps and institutional affiliations.

Copyright: (c) 2021 by the authors. Licensee MDPI, Basel, Switzerland. This article is an open access article distributed under the terms and conditions of the Creative Commons Attribution (CC BY) license (https:// creativecommons.org/licenses/by/ $4.0 /)$.
Abstract: An important challenge in the field of anticancer chemotherapy is the search for new species to overcome the resistance of standard drugs. An interesting approach is to link bioactive ligands to metal fragments. In this work, we have synthesized a set of $p$-cymene-Ru or cyclopentadienyl-M $(\mathrm{M}=\mathrm{Rh}$, Ir) complexes with four chrysin-derived pro-ligands with different -OR substituents at position 7 of ring A. The introduction of a piperidine ring on chrysin led to the highly cytotoxic pro-ligand HL4 and its metal complexes L4-M (SW480 and A549 cell lines, cytotoxic order: L4-Ir > $\mathbf{L} 4-\mathbf{R u} \approx \mathbf{L} 4-\mathbf{R h}) . \mathbf{H L} 4$ and its complexes induce apoptosis and can overcome cis-platinum resistance. However, HL4 turns out to be more cytotoxic in healthy than in tumor cells in contrast to its metal complexes which displayed higher selectivity than cisplatin towards cancer cells. All L4-M complexes interact with double stranded DNA. Nonetheless, the influence of the metal is clear because only complex L4-Ir causes DNA cleavage, through the generation of highly reactive oxygen species $\left({ }^{1} \mathrm{O}_{2}\right)$. This result supports the hypothesis of a potential dual mechanism consisting of two different chemical pathways: DNA binding and ROS generation. This behavior provides this complex with a great effectivity in terms of cytotoxicity.

Keywords: chrysin ligands; iridium; ruthenium; rhodium; cancer; metallodrugs; piperidine; half-sandwich

\section{Introduction}

The acquired or intrinsic resistance of standard drugs is a major challenge in cancer treatment [1]. In order to overcome this drawback, new kinds of anticancer agents are the focus of current research as an alternative to the classical organic or platinum-based drugs [2,3]. During recent decades, organometallic anticancer agents have emerged [4-7] as potential pharmaceutical options. More specifically, ruthenium compounds are considered the most promising drug candidates to date, because of their favorable kinetic properties, rich redox chemistry and high selectivity for cancer cells [8-22]. In fact, several ruthenium complexes, such as the octahedral NAMI-A [23] or sodium trans-tetra-chloridobis $(1 \mathrm{H}-$ indazole)ruthenate(III) (IT-139) [15,24-26] complexes as well as arene-Ru(II) derivatives of the RAPTA family [27-30], containing the PTA ligand, or RM175 [31,32], have been 
evaluated as chemotherapeutic agents in clinical trials (see Figure 1). Unfortunately, during a phase I/II study, the clinical activity of NAMI-A was found to be disappointing [33]. Besides, the octahedral Ru complex TLD-1433 is the first Ru(II)-based photosensitizer for photodynamic therapy (PDT) to enter a human clinical trial [34].

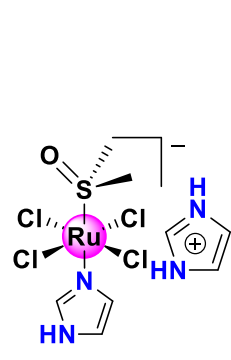

NAMI-A

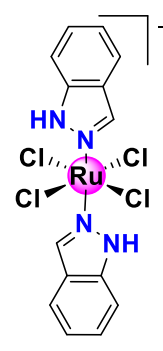

IT-139

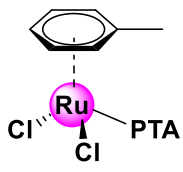

RAPTA-T
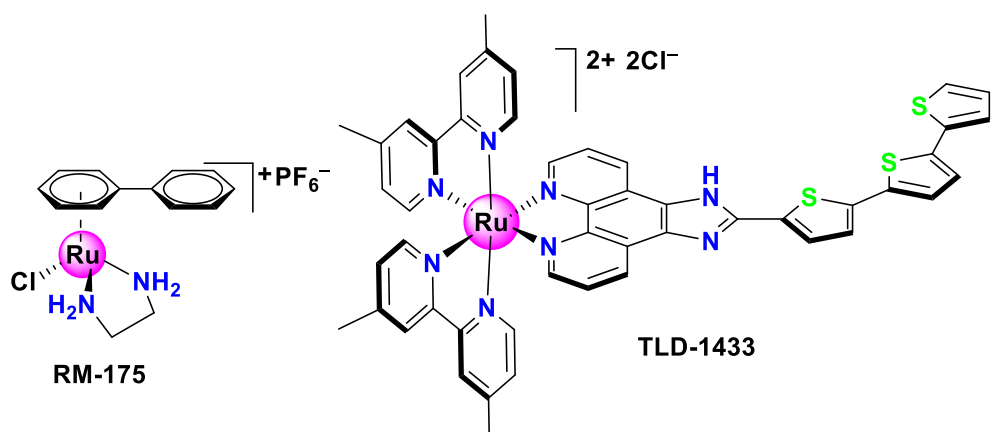

Figure 1. Examples of ruthenium complexes with clinical potential.

Iridium or rhodium complexes have also become the focus of research due to their antiproliferative activity, efficient cellular uptake, and, in some cases, positive tolerance by healthy cells [35-38]. Moreover, half-sandwich organometallic low-spin $\mathrm{d}^{6}$ metal complexes as $\mathrm{Ru}$-arene or $\mathrm{Rh}$ - or Ir-cyclopentadienyl derivatives have attracted great interest as anticancer agents because of the hydrophobic nature of the cyclopentadienyl or arene fragments that can be modulated. These entities can influence the cellular uptake [39-41] and complex stability [42]. Besides, the pharmacological properties of these derivatives can be easily modulated by variation not only of these entities but also of the chelating or monodentate ancillary ligands and the leaving groups [43]. Considering these premises, it is necessary to design innovative complexes that could overcome the limitations of existing drugs.

An interesting approach to address the problem of the resistance in the field of metallic chemotherapeutic agents is to use multi-targeted drugs. This may be achieved by linking bioactive ligands to the metal fragments $[10,22,44,45]$. The compounds thus obtained offer additional advantages over classic anti-cancer agents, such as improved pharmacological properties, tunable antitumor activity, intramolecular combination therapy and selective targeted properties [46]. In this context, flavonoids are a group of naturally occurring plant phenolic compounds that exhibit interesting biological properties including antioxidant behavior [47-49], which depends mostly on the number and position of the hydroxyl groups in their structure, but also anti-inflammatory, estrogenic, antimicrobial and anticancer activity [47,50-52]. Flavonoids act as enzyme inhibitors [53], signaling molecules [54], DNA intercalators [52,55] and chelators of metal ions [56]. Some enzymes targeted by flavone derivatives are important for the growth of cancer cells, a fact that reinforces the design concept of metal-flavone complexes as multitargeted compounds [57]. Amidst flavonoids, quercetin and its metal complexes have been studied in terms of DNA binding studies, in order to establish structure-activity relationships [58]. Recently, Ru [59-66], $\mathrm{V}[67,68], \mathrm{Zn}[69], \mathrm{Cu}[70,71], \mathrm{Fe}$ [72] and La [73] complexes bearing bioactive flavonoids or related ligands have been described. This also include half-sandwich ruthenium [74-77], rhodium $[74,75]$ and osmium $[75,78]$ derivatives that exhibit cytotoxic activity. An excellent review of the biological properties of $\mathrm{Ru}$ complexes with flavonoids ligands has recently appeared [57]. Research on the synthesis of iridium complexes with flavonoids is very scarce; only a flavonol derivative of this metal, active as antioxidant, has been recently reported [79]. The anticancer activity of different flavonoid-containing metal complexes of $\mathrm{Ni}, \mathrm{Zn}, \mathrm{Se}, \mathrm{Mn}$ and $\mathrm{Cu}$ has been reported [71,80]. In the case of $\mathrm{Ru}(\mathrm{II})-p$-cymene derivatives [76] the role played by the ligand system has been evaluated. However, the effect of the metal has been barely analyzed [75]. 
The natural flavone chrysin (5,7-dihydroxy-2-phenyl-4Hchromen-4-one) exhibits interesting pharmacological properties. It reduces oxidative stress in neuronal tissues, neurotoxicity, neuro-inflammation, cognitive dysfunctions [81-83] and also has potential as anticancer agent [84]. To the best of our knowledge, only some recent reports of octahedral $\mathrm{Ru}$ complexes with deprotonated chrysin (chrys) and $\mathrm{N}^{\wedge} \mathrm{N}$ [85,86], chloride [87] or trithiacyclononane [60] as accompanying ligands have been reported. Some of these compounds bind CT DNA and induce apoptosis in cancer cells or additionally have a strong affinity to BSA (bovine serum albumin). With regard to arene complexes, the derivative [( $p$-cym) $\mathrm{RuCl}(\mathrm{chrys})]$ has been shown to modulate platelet activity [88] and similar derivatives with organocalcogen (S,Se) side chains in position 7 of the chrysin structure, exhibited chemotherapeutic activity against breast cancer cells [89]. However, the synthesis and study of the biological properties of half-sandwich Rh and/or Ir complexes with chrysin or chrysin derived ligands have not been addressed.

In this work, we functionalized the -OH group at position 7 of chrysin with alkyl chains with or without terminal groups ( $\mathrm{Br}$, piperidine), in order to modulate their biological properties (see Figure 2). The introduction of the piperidine moiety was based on previous positive effects in the cytotoxic activity after the introduction of this group in chrysin or related derivatives [90,91]. After deprotonation of the chrysin compounds, the anionic species will be able to act as chelators for the metal centers and, in fact, they coordinate to $\mathrm{p}$-cymene-Ru, C $\mathrm{p}^{*}-\mathrm{Rh}$ and $\mathrm{C} \mathrm{p}^{*}$-Ir fragments to afford the corresponding half-sandwich complexes. In this manner, potential multi-targeted compounds will be obtained. Furthermore, the coordination will eliminate the intramolecular hydrogen bond between the $\mathrm{C}=\mathrm{O}$ group on the $5-\mathrm{OH}$ position, a bond that has been proposed to produce low bioavailability [90]. The aim of this work was to carry out a SAR study evaluating the influence not only of the substitution on the ligand but also that of the metal center in their biological properties. We will show that the most cytotoxic species are those containing the ligand L4 and the most promising one is that with iridium as the metal center. The targets were determined, and the results of cytotoxicity-cellular uptake were also examined.
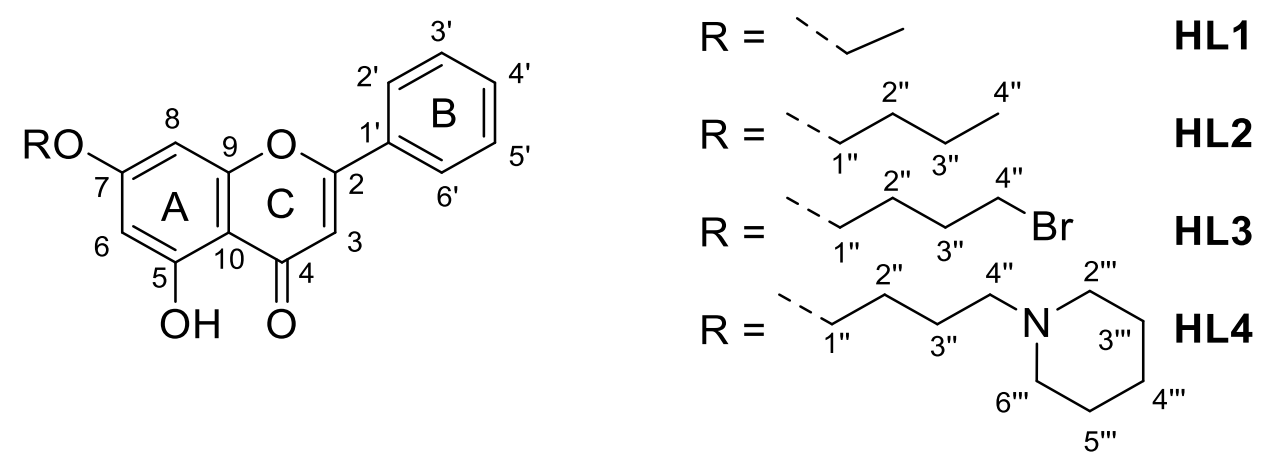

Figure 2. Molecular structure of ligand precursors (HL1-HL4) and atom numbering scheme.

\section{Materials and Methods}

All reactions, except where noted, were carried out under an atmosphere of dry oxygen-free nitrogen using standard Schlenk techniques. Solvents were distilled under inert atmosphere from the appropriate drying agents and degassed before use or purified in a MBraun SPS MB-SPS-800 from commercial HPLC solvents. Piperidine was distilled prior to use. $\mathrm{CDCl}_{3}$ was deoxygenated and distilled. Reactions requiring heat were performed with thermostated oil baths. Elemental analyses were performed with a Thermo Quest FlashEA 1112 microanalyser and IR spectra on a Shimadzu IR Prestige-21 infrared spectrometer equipped with a Pike Technologies ATR. The $\mathrm{FAB}^{+}$mass spectrometry measurements were obtained with a Thermo MAT95XP mass spectrophotometer with a magnetic sector. NMR spectra were recorded on Varian Innova 500 and Varian Unity $400 .{ }^{1} \mathrm{H}$ and ${ }^{13} \mathrm{C}\left\{{ }^{1} \mathrm{H}\right\} \mathrm{NMR}$ chemical shifts are reported in ppm referenced to TMS. For ${ }^{1} \mathrm{H}-{ }^{13} \mathrm{C} \mathrm{g}-\mathrm{HMQC}$ spectra, the standard Varian pulse sequences were used (VNMR 6.1 C software). The spectra were 
acquired using $16096 \mathrm{~Hz}\left({ }^{1} \mathrm{H}\right)$ and $25133.5 \mathrm{~Hz}\left({ }^{13} \mathrm{C}\right)$ widths; 16 transients of 2048 data points were collected for each of the 256 increments. In the NMR analysis s, d, t, q, qt, sex, sept, $\mathrm{m}$ and bs denote singlet, doublet, triplet, quartet, quintuplet, sextuplet, septuplet, multiplet and broad signal, respectively. Unless otherwise stated, the ${ }^{13} \mathrm{C}\left\{{ }^{1} \mathrm{H}\right\} \mathrm{NMR}$ signals are singlets. The proligands HL1-HL2 [92,93], HL3 [47,94-98] and HL4 [47,95] and the metal precursors $\left[\mathrm{Ru}\left(\boldsymbol{\square}^{6}-p \text {-cym }\right) \mathrm{Cl}_{2}\right]_{2}(p$-cym $=p$-cymene $)[99,100]$ or $\left[\mathrm{M}\left(\mathbf{(}^{5}-\mathrm{Cp}^{*}\right) \mathrm{Cl}_{2}\right]_{2}(\mathrm{M}=\mathrm{Rh}, \mathrm{Ir}$, $\mathrm{Cp}^{*}=$ pentamethylcyclopentadienyl) [101] were prepared by published procedures.

Information regarding the synthesis and characterization of the 12 new $\mathrm{Ru}, \mathrm{Rh}$ and Ir complexes is gathered in the Supplementary Materials.

\subsection{Crystal Data for $\mathbf{H L 2}$}

Suitable crystals of HL2 were grown from a toluene/pentane mixture. Intensity data were collected at $290 \mathrm{~K}$ on a Bruker X8 APEX II CCD-based diffractometer, equipped with a graphite monochromated $\operatorname{MoK} \alpha$ radiation source $(\lambda=0.71073 \AA)$. Data were integrated using SAINT [102] and an absorption correction was performed with the program SADABS [103]. The structure was solved by direct methods using WINGX package [104,105], and refined by full-matrix least-squares methods based on $F^{2}$. Hydrogen atoms were placed using a "riding model" and included in the refinement at calculated positions. The CCDC deposition number is 2019578.

\subsection{General Procedure for Stability Studies by NMR Spectroscopy}

For the stability in DMSO- $d_{6}$, the complexes L4-Ru, L4-Rh, and L4-Ir (5 mg) were dissolved in $300 \mu \mathrm{L}$ DMSO- $d_{6}$ (approx. $2.1 \times 10^{-2} \mathrm{M}$ ), and ${ }^{1} \mathrm{H}$ NMR spectra were recorded during $24 \mathrm{~h}$ in a $400 \mathrm{MHz}$ spectrometer.

For the aquation studies, $200 \mu \mathrm{L}$ of $\mathrm{D}_{2} \mathrm{O}$ (approx. $1.5 \times 10^{-2} \mathrm{M}$ ) was added over the previous solution, and ${ }^{1} \mathrm{H}$ NMR spectra were recorded during $24 \mathrm{~h}$ in a $400 \mathrm{MHz}$ spectrometer.

\subsection{Cell Lines Culture}

Human colon cancer (SW480), lung adenocarcinoma (A549) and lung fibroblasts (IMR90) cells from the ECACC (European Collection of Authenticated Cell Cultures, Salisbury, UK) were cultured in Dulbecco's Modified Eagle's Medium (DMEM) supplemented with $10 \%$ fetal bovine serum (FBS) and 1\% amphotericin-penicillin-streptomycin solution. Ovarian cancer (A2780) and cisplatin resistant ovarian cancer cells (A2780cis) cells were cultured in RPMI-1640 supplemented with $2 \mathrm{mM}$ of Glutamine, $10 \%$ fetal bovine serum (FBS) and 1\% amphotericin-penicillin-streptomycin solution. Cells were incubated at $37^{\circ} \mathrm{C}$ under a humidified 5\% $\mathrm{CO}_{2}$ atmosphere.

\subsection{Antiproliferative Activity}

Antiproliferative activity was evaluated by the MTT Assay as previously described [106]. Briefly, cells were seeded in 96-well plates at a density of $5 \times 10^{3}$ (IMR-90 and A549) or $1 \times 10^{4}$ (SW480, A2780 and A2780cis) and incubated for $24 \mathrm{~h}$. After attachment to the surface, the cells were incubated with various concentrations of the studied complexes, freshly dissolved in DMSO and diluted in the culture medium. Then, $100 \mu \mathrm{L}$ of $500 \mu \mathrm{g} / \mathrm{mL}$ of thiazolyl blue tetrazolium bromide (MTT) was added to each well. After $4 \mathrm{~h}$, the formazan product was dissolved by adding $100 \mu \mathrm{L}$ of $10 \%$ sodium dodecyl sulfate (SDS) in $0.01 \mathrm{M} \mathrm{HCl}$ and incubated overnight. Absorbance was read at $590 \mathrm{~nm}$ in a microplate reader. Cisplatin was also included as a positive control. Half maximal inhibitory concentration $\left(\mathrm{IC}_{50}\right)$ values, expressed as percentage values respect to the controls, were calculated using the GrahPad Prism 6.01 analysis software from three independent experiments.

\subsection{Cellular Uptake Studies}

To study cellular uptake by inductively coupled plasma-mass spectrometry (ICP-MS), $1.5 \times 10^{5}$ A549 cells were seeded in $2 \mathrm{~mL}$ DMEM culture medium in 6-well plates for $24 \mathrm{~h}$ 
at $37{ }^{\circ} \mathrm{C}$ and $5 \% \mathrm{CO}_{2}$. Then cells were treated at a determined concentration for $24 \mathrm{~h}$ and they were harvested, centrifuged and re-suspended in phosphate buffered saline (PBS). Finally, samples were digested with $65 \% \mathrm{HNO}_{3}$ at room temperature for $24 \mathrm{~h}$ and diluted with Mili-Q water to obtain final $2 \% \mathrm{HNO}_{3}$ solutions before being analyzed by ICP-MS.

\subsection{Intracellular ROS Generation}

A549 cells were seeded in 12-well plates at a density of $4 \times 10^{4}$ cells / well and incubated for $24 \mathrm{~h}$ at $37^{\circ} \mathrm{C}$ and $5 \% \mathrm{CO}_{2}$. Then, cells were incubated for $30 \mathrm{~min}$ with $25 \mu \mathrm{M}$ of $\mathrm{H}_{2}$ DCFDA in DMEM medium without phenol red and 1\% FBS. Then, cells were washed twice with DPBS and incubated with the compounds under study in complete medium at their half maximal inhibitory concentration for other $4 \mathrm{~h}$. A total of $20 \mu \mathrm{M}$ of TBH were included as positive control. After treatment, cells were harvested and washed with DPBS. Data were collected in a NovoCyte Flow cytometer (ACEA Biosciences, Inc., Diego, CA, USA). A total of 10,000 events per sample were counted and analyzed by NovoExpress 1.4.0 Software. Three replicates and two independent experiments were performed.

\subsection{Apoptosis Detection}

Apoptosis was evaluated by an Annexin V:FITC Assay Kit (Biorad, Hercules, CA, USA) according to the manufacturer's instructions. Data were collected in a NovoCyte Flow cytometer (ACEA Biosciences, Inc., Diego, CA, USA). A total of 10,000 events were counted and analyzed by NovoExpress 1.4.0 Software. Two replicates and two independent experiments were performed.

\subsection{Cell Cycle Arrest}

A total of $1.5 \times 10^{5}$ A549 cells per well were seeded in 6-well plates and incubated for $24 \mathrm{~h}$. Then, cells were treated at the $\mathrm{IC}_{50}$ value for each compound. Cells without any treatment and vehicle-treated cells $(0.5 \%$ DMSO) were used as control. After $24 \mathrm{~h}$ of treatment, cells were harvested and centrifuged, resuspended in cold PBS and fixed in $70 \%$ EtOH overnight at $4{ }^{\circ} \mathrm{C}$. Then, samples were treated with $0.1 \mathrm{mg} / \mathrm{mL}$ PI, $0.1 \mathrm{mM}$ EDTA and $0.1 \%$ Triton- $\times 100$ in PBS to permeabilize and stain cells, and with RNAse (2 $\mathrm{mg} / \mathrm{mL}$ ) for $30 \mathrm{~min}$ in ice and protected from light. Finally, cells were analyzed using the NovoCyte Flow cytometer (ACEA Biosciences, Inc., Diego, CA, USA). Cell cycle distribution was evaluated by NovoExpress 1.4.0 Software. Two replicates were included, and two independent experiments were performed.

\subsection{Statistical Analysis}

All the results were expressed as the mean with the standard deviation. Statistical analysis was performed by ANOVA with Dunnet's Test for multiple comparison with the software GraphPad Prism 6.

\subsection{UV-Vis Spectroscopy}

Absorbance spectra were performed on a Hewlett-Packard 8453A (Agilent Technologies, Santa Clara, CA, USA) spectrophotometer fitted out with a Peltier temperature control system at $\mathrm{T}=25^{\circ} \mathrm{C}$ in $1.0 \mathrm{~cm}$ path-length cells. Substitution or binding kinetics were measured analyzing the absorbance change of the complexes solutions recorded over time. The melting experiments were carried out using a DNA solution in three $C_{D} / C_{P}$ ratios: 0 , 0.05 and 0.5 , recording the absorbance spectra while heating from 30 to $90{ }^{\circ} \mathrm{C}$ at $0.3^{\circ} \mathrm{C} / \mathrm{min}$.

\subsection{Circular Dichroism Spectroscopy}

CD measurements were performed with a MOS-450 biological spectrophotometer (Bio-Logic SAS, Claix, France) fitted out with $1.0 \mathrm{~cm}$ path length cells. Samples were prepared incubating DNA with flavonoid complexes overnight in $2.5 \mathrm{mM}$ sodium cacodylate $(\mathrm{NaCaC})$ buffer at $\mathrm{pH}=7.0$ and $\mathrm{T}=25^{\circ} \mathrm{C}$. Spectrograms were obtained in the 200-600 $\mathrm{nm}$ range at $2 \mathrm{~nm} / \mathrm{s}$ speed. Molar ellipticity (Deg $\mathrm{M}^{-1} \mathrm{~cm}^{-1}$ ) was calculated 
using $[\theta]=100 \cdot \theta / C_{P} \cdot 1$, where $C_{P}$ is the polynucleotide concentration and 1 is the cell light path $(\mathrm{cm})$.

\subsection{Viscosity Measurements}

A Micro-Ubbelohde viscometer whose temperature was controlled externally $\left(25 \pm 0.1^{\circ} \mathrm{C}\right)$ was used for viscosity measurements. The flow time was measured with a digital stopwatch. Mean values of triplicated measurements were taken to evaluate the DNA viscosity in the absence $\left(\eta_{0}\right)$ and in the presence, $(\eta)$ of iridium complexes. The viscosity readings were expressed as $L / L_{0}=\left(\eta / \eta_{0}\right)^{1 / 3}$ versus $C_{D} / C_{P}$ ratio.

\subsection{Native Polyacrylamide Gel Electrophoresis (PAGE)}

Native PAGE was performed as previously described [106]. Briefly, $1.5 \mu \mathrm{M}$ of BSA was incubated with different complex concentrations in Tris $\mathrm{HCl}$ buffer $(0.5 \mathrm{M}, \mathrm{pH}=6.8$. Then samples were loaded in $10 \%$ polyacrylamide gel BSA, which was immersed in tris borate and EDTA (TBE) $1 \mathrm{X}$ buffer. The gel was run at $6.6 \mathrm{~V} / \mathrm{cm}$ for $4 \mathrm{~h}$ at $4{ }^{\circ} \mathrm{C}$ and then stained with Coomassie Brilliant Blue R-250. Finally, the gel was visualized with a Bio-Rad Gel Doc XR+ Imaging System.

\subsection{Plasmidic Electrophoresis Assays}

Agarose gel electrophoresis of plasmid DNA pUC18 was performed using 1\% agarose gel in TBE buffer and ethidium bromide as staining agent. The samples were prepared by mixing $23.8 \mu \mathrm{M}$ of pUC18 plasmid with different concentration of the studied compounds being the final [complex]/[plasmid] ratios of 5, 10 and 20. The samples were incubated overnight. Afterwards, $2 \mu \mathrm{L}$ of loading buffer (Bio-Rad, Glycerol 25\%) were added for a $12 \mu \mathrm{L}$ final volume. After homogenization, electrophoresis was run at $5 \mathrm{~V} / \mathrm{cm}$ during $1 \mathrm{~h}$ and the gel was visualized with a Bio-Rad Gel Doc XR+ Imaging System. Another electrophoresis was carried out in the same way incubating the samples with ROS scavengers.

\section{Results and Discussion}

\subsection{Synthesis and Characterization of the Ligands and Complexes}

The proligands HL1, HL2 [92,93] and HL3 [47,94-98] were obtained from the treatment of chrysin with $\mathrm{K}_{2} \mathrm{CO}_{3}$ and the corresponding bromo or dibromo alkanes. Reaction of $\mathrm{HL} 3$ with piperidine and $\mathrm{K}_{2} \mathrm{CO}_{3}$ yielded $\mathrm{HL} 4[47,95]$. The proligands were then deprotonated with $\mathrm{NaHCO}_{3}$ and the obtained L1-L4 anionic species were made to react with $\left[\mathrm{Ru}\left(\eta^{6}-p \text {-cym }\right) \mathrm{Cl}_{2}\right]_{2}(p$-cym $=p$-cymene $)$ or $\left[\mathrm{M}\left(\eta^{5}-\mathrm{Cp}^{*}\right) \mathrm{Cl}_{2}\right]_{2}\left(\mathrm{M}=\mathrm{Rh}, \mathrm{Ir} ; \mathrm{Cp}^{*}=\right.$ pentamethylcyclopentadienyl) dimers, to afford 12 new complexes of general formula [ $\left.\mathrm{LMCl}\left(\mathrm{O}^{\wedge} \mathrm{O}\right)\right]$, where $\mathrm{L}=p$-cym, $\mathrm{Cp}^{*}$ (see Scheme 1 ).

The proligands HL1-HL4 and the complexes were fully characterized by elemental analysis, mass spectrometry, IR and ${ }^{1} \mathrm{H}$ and ${ }^{13} \mathrm{C}\left\{{ }^{1} \mathrm{H}\right\}$ NMR spectroscopy. The assignment of the different resonances was based on the literature data $[60,95,98,101-108]$ and $2 \mathrm{D}$ NMR experiments.

In the IR spectra of HL1-HL4, the $v(\mathrm{C}=\mathrm{O})$ vibration appears in the range 1651$1661 \mathrm{~cm}^{-1}$, while for the respective complexes the band is displaced to lower wavenumbers $\left(1627-1636 \mathrm{~cm}^{-1}\right)$, a fact that reflects the involvement of the $\mathrm{C}=\mathrm{O}$ group in the coordination to the metal centers [109].

The ${ }^{1} \mathrm{H}$ NMR spectra of HL1-HL4 displayed a broad singlet at 12.61-12.70 ppm for the phenolic hydroxyl group. The low field of these resonances suggests its participation in intramolecular hydrogen bonding interactions (observed in the solved X-ray diffraction structure for HL2, vide infra, or that of HL3) [97]. As expected, this resonance disappears upon complex formation. The position of the resonances of ligands and complexes are reflected in Table S1 of SI. No significant differences in the chemical shifts of protons $3^{\prime}$, $4^{\prime}$ and $5^{\prime}$ of ring B of the L4-M complexes were observed and small shifts were detected for protons of $A$ and $C$ rings $[95,98,108]$. In the case of the ruthenium complexes, the lack of symmetry leads to the observation of two different isopropylic methyl groups 
for the $p$-cymene fragment (see ${ }^{1} \mathrm{H}$ and ${ }^{13} \mathrm{C}\left\{{ }^{1} \mathrm{H}\right\} \mathrm{NMR}$ spectra and characterization in SI). Interestingly, four aromatic $\mathrm{CH}$ groups were observed in the ${ }^{13} \mathrm{C}\left\{{ }^{1} \mathrm{H}\right\} \mathrm{NMR}$ spectra, although only two proton resonances for these groups were observed in each complex.

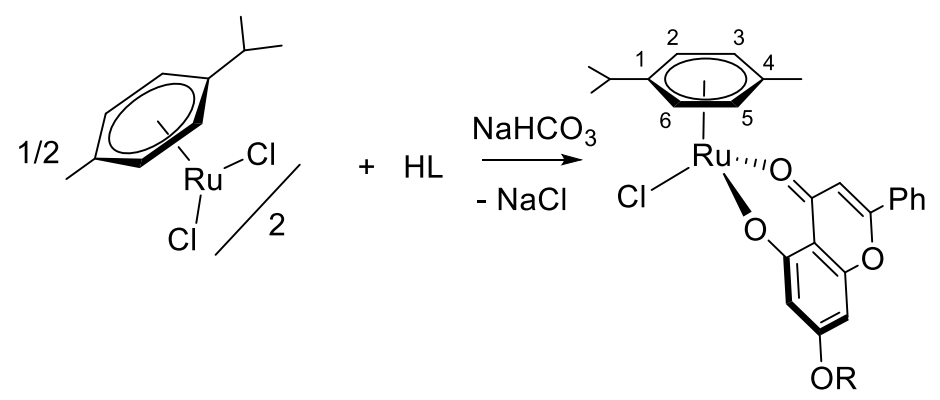

$$
\begin{aligned}
& \mathrm{R}=\mathrm{Et}, \quad \mathrm{L}=\mathbf{L} \mathbf{1}, \mathbf{L} \mathbf{-}-\mathbf{R u} \\
& \mathrm{R}=n-\mathrm{Bu}, \quad \mathrm{L}=\mathrm{L2}, \mathrm{L} 2-\mathrm{Ru} \\
& \mathrm{R}=-\left(\mathrm{CH}_{2}\right)_{4}-\mathrm{Br}, \mathrm{L}=\mathrm{L3}, \mathrm{L3}-\mathrm{Ru} \\
& \mathrm{R}=-\left(\mathrm{CH}_{2}\right)_{4} \text {-pip, } \mathrm{L}=\mathbf{L 4} \text {, L4-Ru } \\
& \text { pip }=\text { piperidine }
\end{aligned}
$$

$1 / 2$

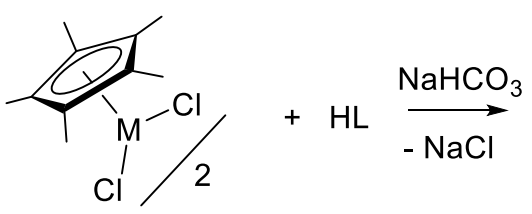

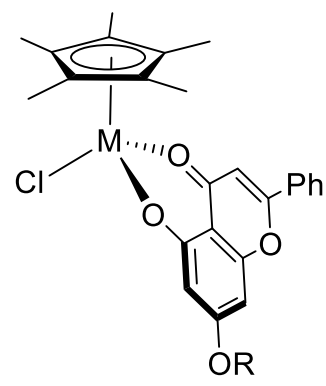

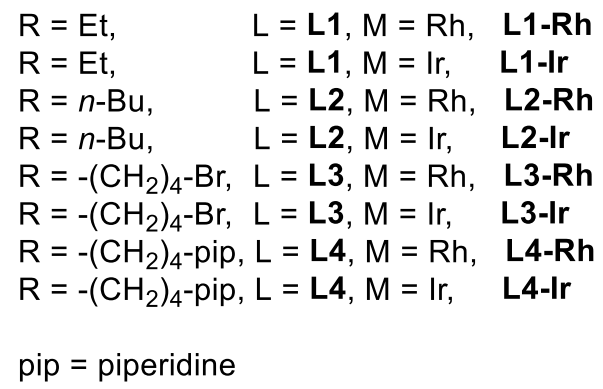

Scheme 1. Synthesis and molecular structure of the new $\mathrm{Ru}, \mathrm{Rh}$ and $\mathrm{Ir}$ complexes containing chrysin derived ligands.

Unsuccessful attempts of crystallization of the metal complexes were performed. Nevertheless, the unknown structure of proligand HL2 was solved by single crystal X-Ray diffraction. The corresponding ORTEP representation is shown in Figure 3. The crystallographic data and the table with the distances and angles are collected in the Supplementary Materials (Tables S2 and S3, respectively). Rings A and C are coplanar as expected, but ring $B$ deviates slightly from coplanarity relative to the condensed unit AC, showing a dihedral angle of $7.4^{\circ}$. The expected intramolecular hydrogen bond $\mathrm{O} 2 \cdots \mathrm{H} 1$ was observed with a distance of $1.84 \AA$. There were also a series of intermolecular hydrogen bonds, and it is worth noting the formation of dimers thanks to double head-to-tail hydrogen bonds involving $\mathrm{H} 11$ and O2 (see Figure S1 and Table S4).

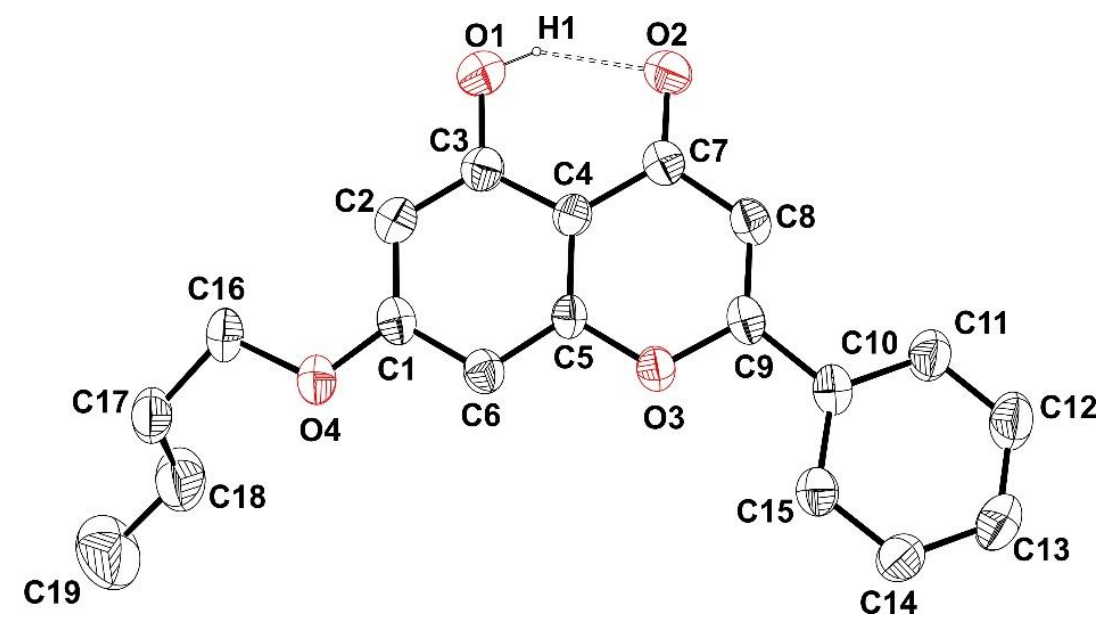

Figure 3. ORTEP representation of HL2 (ellipsoids at the $30 \%$ probability). Hydrogen atoms have been omitted for clarity. 


\subsection{Cytotoxic Activity}

The antiproliferative activity of the four proligands HL1-HL4 and their metal complexes was firstly evaluated in human colon (SW480) and lung (A549) cancer cells. The calculated half maximal inhibitory concentration, $\mathrm{IC}_{50}$ values, are gathered in Table 1 . As can be observed, the ligand structure plays an essential role in the activity of the complexes. Among the ligands HL1-HL3, only HL3 presents slight activity against A549 cells, whilst HL4 is cytotoxic to both cell lines, with $\mathrm{IC}_{50}$ values lower than those found for the control cisplatin. The observed cytotoxicity of the ligands determines the cytotoxic potential of the corresponding metal complexes to some extent. While $\mathbf{L} 2$-complexes are inactive towards both cancer cell lines, L1-Rh and L1-Ir exhibit low or moderate cytotoxicity in the SW480 cell line, respectively. L3-Rh and L3-Ir are cytotoxic in A549 cells (being L3-Ir more active), while no activity against SW480 is observed. On the other hand, as was observed for HL4, its complexes present higher cytotoxic activity than cisplatin in both cell lines, and in particular L4-Ir is the most cytotoxic derivative among the L4-M family and among all the new complexes. Therefore, the results show that the activity of the chrysin derived metal complexes depends not only on the ligand (see Figure 2) but also on the nature of the metal center.

Table 1. $\mathrm{IC}_{50}$ values expressed in $\mu \mathrm{M}$ after an exposition period of $24 \mathrm{~h}$ for all the synthesized complexes and their ligands in colon (SW480) and lung (A549) cancer cell lines.

\begin{tabular}{cccccc}
\hline Complex & SW480 & A549 & Complex & SW480 & A549 \\
\hline L1-Ru & $95.7 \pm 5.2$ & $159.9 \pm 1.2$ & L3-Ru & $117.3 \pm 3.2$ & $114.9 \pm 1.2$ \\
\hline L1-Rh & $33.5 \pm 1.1$ & $134.4 \pm 1.1$ & L3-Rh & $>200$ & $57.3 \pm 1.1$ \\
\hline L1-Ir & $51.9 \pm 1.6$ & $>200$ & L3-Ir & $>200$ & $36.8 \pm 1.2$ \\
\hline HL1 & $>200$ & $>200$ & HL3 & $>200$ & $63.7 \pm 1.2$ \\
\hline L2-Ru & $134.1 \pm 9.2$ & $122.6 \pm 1.2$ & L4-Ru & $28.5 \pm 1.3$ & $31.1 \pm 1.6$ \\
\hline L2-Rh & $124.2 \pm 1.1$ & $97.4 \pm 1.2$ & L4-Rh & $31.3 \pm 1.3$ & $35.3 \pm 1.0$ \\
\hline L2-Ir & $119.8 \pm 1.1$ & $>200$ & L4-Ir & $15.9 \pm 1.3$ & $18.9 \pm 1.1$ \\
\hline HL2 & $>200$ & $>200$ & HL4 & $20.8 \pm 2.0$ & $23.8 \pm 2.1$ \\
\hline CDDP ${ }^{1}$ & $46.7 \pm 1.4$ & $37.6 \pm 1.3$ & & &
\end{tabular}

In view of the higher potential of HL4 and its metal complexes as anticancer agents, an in-depth study was carried out with them. The cytotoxic activity of HL4 and its metal complexes in a non-malignant lung fibroblast cell line (IMR-90) was evaluated in order to study the selectivity of the complexes under study against tumor cells (Table 2). According to the calculated selectivity index $\left(\mathrm{SI}=\mathrm{IC}_{50}(\mathrm{IMR}-90) / \mathrm{IC}_{50}(\mathrm{~A} 549)\right)$, the free ligand is not selective at all, being even more cytotoxic in the tested healthy cells than in tumor cells, while all the complexes display higher selectivity than cisplatin. The cytotoxicity against ovarian cancer cells sensitive (A2780) and resistant to cisplatin (A2780) was also evaluated (Table 2). Thus, HL4 and its metal complexes are able to circumvent cisplatin resistance. What is more, $\mathbf{L 4}$ - Ru and $\mathbf{L 4 - R \mathbf { h }}$ are more cytotoxic against cisplatin resistant cells than against sensitive cells. 
Table 2. $\mathrm{IC}_{50}$ values expressed in $\mu \mathrm{M}$ after an exposition period of $24 \mathrm{~h}$ for HL4 and L4 complexes, in healthy human lung fibroblasts (IMR-90) and ovarian cancer cells (A2780) sensitive and resistant to cisplatin (A2780cis). Calculated selectivity index ( $\left.\mathrm{SI}=\mathrm{IC}_{50}(\mathrm{IMR}-90) / \mathrm{IC}_{50}(\mathrm{~A} 549)\right)$ and resistance factor $\left(\mathrm{RF}=\mathrm{IC}_{50}(\mathrm{~A} 2780 \mathrm{cis}) / \mathrm{IC}_{50}(\mathrm{~A} 2780)\right)$.

\begin{tabular}{cccccc}
\hline Complex & IMR-90 & SI & A2780 & A2780cis & RF \\
\hline L4-Ru & $54.5 \pm 1.1$ & 1.8 & $14.9 \pm 1.8$ & $8.4 \pm 0.4$ & 0.6 \\
\hline L4-Rh & $55.6 \pm 1.0$ & 1.6 & $23.3 \pm 2.1$ & $4.9 \pm 0.2$ & 0.2 \\
\hline L4-Ir & $33.8 \pm 1.2$ & 1.8 & $22.7 \pm 3.0$ & $23.5 \pm 1.8$ & 1.0 \\
\hline HL4 & $5.1 \pm 1.3$ & 0.2 & $8.8 \pm 0.6$ & $13.0 \pm 1.6$ & 1.5 \\
\hline CDDP ${ }^{1}$ & $57.7 \pm 1.2$ & 1.5 & $7.0 \pm 0.7$ & $60.1 \pm 4.3$ & 8.6 \\
\hline${ }^{1}$ CDDP = Cisplatin. & & & &
\end{tabular}

\subsection{NMR Stability Studies of the Complexes with L4 in DMSO- $d_{6}$ and DMSO- $d_{6} / \mathrm{D}_{2} \mathrm{O}(3: 2)$}

The study of the behavior of new anticancer agents in aqueous solution is crucial to reveal their stability. Moreover, when $\mathrm{M}-\mathrm{Cl}$ bonds are present, it is important to determine whether the chloride ligand is exchanged by a water molecule to give the more reactive aqua-complex in aqueous media [76]. In fact, hydrolysis of $\mathrm{M}-\mathrm{Cl}$ bonds is often an activation step for the reactivity of the transition metal anticancer complexes. Considering the higher cytotoxic activity of the complexes containing L4, stability studies were performed for the L4-M (M = Ru, Rh and Ir) derivatives. Due to the lack of solubility of these complexes in $\mathrm{D}_{2} \mathrm{O}$, the biological studies were performed in a $\mathrm{D}_{2} \mathrm{O}$ /DMSO mixture (maximum amount of DMSO, $0.5 \%$ ). Thus, the stability of freshly prepared solutions of the complexes in DMSO- $d_{6}$ was studied first. Afterwards the aquation process was analyzed by addition of $\mathrm{D}_{2} \mathrm{O}$ over the previous solution (see Section 2). In spite of the fact that these NMR studies were necessarily performed in conditions of solvent and concentration different from those of the biological experiments, it is important to notice that they offer valuable information concerning the reactivity of the complexes.

\subsubsection{NMR Stability Studies of the Complexes Containing L4 in DMSO- $d_{6}$}

The stability of the complexes $\mathbf{L} 4-\mathbf{M}\left(\mathbf{M}=\mathrm{Ru}, \mathrm{Rh}\right.$ and Ir) was studied in DMSO- $d_{6}$ solution in order to know the speciation in the stock solution. After $24 \mathrm{~h}$, there were significant differences in the stability of the complexes depending on the metallic center. All the studied compounds presented partial release of the chrysin ligand, as has been previously observed for similar $\mathrm{Ru}$ complexes with anionic $\mathrm{O}^{\wedge} \mathrm{O}$ ligands [110,111]. The fact that, in the aromatic region, only another species is observed, apart from HL4, even after $24 \mathrm{~h}$ led us to tentatively propose that this species is the DMSO- $d_{6}$ adduct, which will be noted as L4-M(S) ([ArM(L4)(DMSO) $]^{+}, \mathrm{Ar}=p$-cym or $\left.\mathrm{Cp}^{*}\right)$ [112].

The most stable complex in DMSO- $d_{6}$ was L4-Ru, with an $8 \%$ of HL4 in solution and $92 \%$ of L4-Ru(S) (see Figure S2 and Figure 2, spectrum a). For L4-Rh, although L4$\mathbf{R h}(\mathbf{S})$ is the major species, 39\% of HL4 (free ligand) was observed (see Figure S3). The presence of the HL4 signals is concomitant with the apparition of a new Cp* resonance (1.62 ppm), which could correspond to species of the type $\left.\left[\mathrm{Cp}^{*} \mathrm{RhZ}\right]_{3}\right]^{\mathrm{n}+}\left(\mathrm{Z}=\mathrm{Cl}, \mathrm{H}_{2} \mathrm{O}\right.$ or DMSO) $[113,114]$. For complex L4-Ir, the ${ }^{1} \mathrm{H}$ NMR spectra showed that the signals of the starting product decreased with time, while broad resonances appeared in the aromatic region (especially those for rings $A$ and $C$, since ring $B$ is less affected by the coordination of HL4, vide supra), along with a new $\mathrm{Cp}^{*}$ signal at $1.63 \mathrm{ppm}$. The signal for the $\mathrm{OH}$ group was also observed (12.8 ppm). We propose that the signals for $\mathbf{H L} 4$ are broad, because the free ligand is interacting with species of the type $\left[\mathrm{Cp}^{*} \mathrm{IrZ}_{3}\right]^{\mathrm{n}+}\left(\mathrm{Z}=\mathrm{H}_{2} \mathrm{O}\right.$ or DMSO) [115] (see Figure S4). 


\subsubsection{NMR Stability Studies of the Complexes with L4 in DMSO- $d_{6} / \mathrm{D}_{2} \mathrm{O}(3: 2)$}

After addition of $\mathrm{D}_{2} \mathrm{O}$ over the solution of $\mathbf{L} 4-\mathbf{R u}(\mathbf{S})$ in DMSO- $d_{6}$ (see Experimental section and Figure 4), the signal for $\mathrm{OH}$ group disappeared from the spectrum by protondeuterium exchange with $\mathrm{D}_{2} \mathrm{O}$ (compare a and $\mathrm{b}$ in Figure 2). The ${ }^{1} \mathrm{H}$ NMR spectra showed the instantaneous formation of a new species that is proposed to be the aqua complex $\left[(p \text {-cym }) \mathrm{Ru}(\mathbf{L} \mathbf{4})\left(\mathrm{H}_{2} \mathrm{O}\right)\right]^{+}$. It has been reported that the solution of $\mathrm{Ru}($ arene) compounds featuring an $\mathrm{O}^{\wedge} \mathrm{O}$-chelating motif and a chloride ligand in water often results in a rapid exchange of this chloride ligand by a water molecule $[76,116,117]$. The broadening of the aqua complex resonances may be due to interconversion processes, possibly involving protonation of the coordinated L4 ligand [118]. The evolution with time of this aqua species to the formation of free $\mathbf{H L} 4$ and the hydroxo dimer species $\left[(p-c y m) \mathrm{Ru}(\mu-\mathrm{OH})_{3} \mathrm{Ru}(p\right.$ cym)] [76,117,119] (two doublet signals at 5.03 and $5.23 \mathrm{ppm}$ and a doublet at $1.10 \mathrm{ppm}$ for the isopropylic methyl group, see Figure S5) is also observed. The formation of this dimer has been previously described for Ru-( $p$-cym)-flavonoids and similar complexes containing other $\mathrm{O}^{\wedge} \mathrm{O}$ ligands $[76,116,118,119]$. The formation of the aqua complex should increase the acidity of the water molecule that could be able to protonate $\mathbf{L} 4$, giving rise to the partial formation of HL4 and the hydroxo species. This has been previously proposed for relatively similar Ru and Os complexes [118]. The formation of the hydroxo dimer may favor the latter process (this type of behavior may also be possible for Rh or Ir complexes, vide infra). Thus, after $24 \mathrm{~h}$, three species are present in solution: HL4, $\left[(p-c y m)_{2} \mathrm{Ru}_{2}(\mu-\mathrm{OH})_{3}\right]$ and $\left[(p-c y m) \mathrm{Ru}(\mathbf{L} \mathbf{4})\left(\mathrm{H}_{2} \mathrm{O}\right)\right]^{+}$.

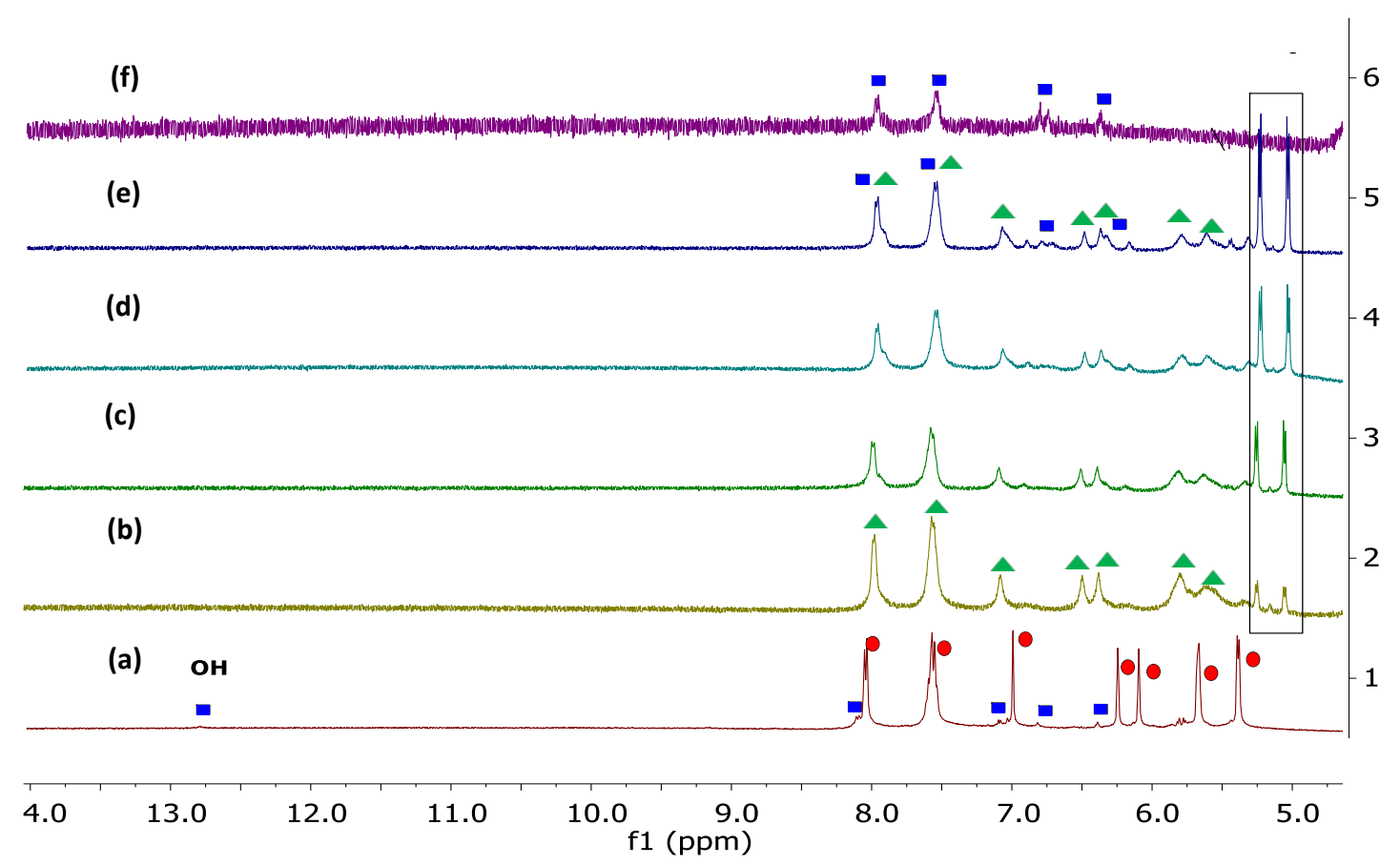

Figure 4. Aromatic area of ${ }^{1} \mathrm{H}$ NMR spectra (400 MHz) for L4-Ru: in DMSO- $d_{6}$ after $24 \mathrm{~h}$; and in DMSO- $d_{6}: \mathrm{D}_{2} \mathrm{O}(3: 2)$ (400 MHz): (a) L4-Ru after $24 \mathrm{~h}$ in DMSO- $d_{6} ;(\mathbf{b}) \mathrm{t}=0$; (c) $\mathrm{t}=3 \mathrm{~h} ;(\mathbf{d}) \mathrm{t}=7 \mathrm{~h} ;(\mathbf{e}) \mathrm{t}=24 \mathrm{~h}$; (f) free ligand HL4. Red circles, $\mathrm{L} 4-\mathrm{Ru}(\mathrm{S})$; green triangles, $\left[(p\right.$-cym $\left.) \mathrm{Ru}(\mathrm{L} 4)\left(\mathrm{H}_{2} \mathrm{O}\right)\right]+$; blue squares, HL4. The resonances inside the black rectangle correspond to $\left[(p-c y m)_{2} \mathrm{Ru}_{2}(\mu-\mathrm{OH})_{3}\right]$. Time values refer to the addition of $\mathrm{D}_{2} \mathrm{O}$.

After the addition of $\mathrm{D}_{2} \mathrm{O}$ over the solution of $\mathbf{L} 4-\mathbf{R h}(\mathbf{S})$, the aromatic region reflects the existence of a new set of single and broad signals (Figure S6). However, the aliphatic region (Figure S7) shows the existence of several $\mathrm{Cp}^{*}$ containing species. We propose that the derivative containing ligand $\mathbf{L} 4$ is $\left[\mathrm{Cp}^{*} \mathrm{Rh}(\mathbf{L} 4)\left(\mathrm{H}_{2} \mathrm{O}\right)\right]^{+}$that could be in fast equilibrium with other species resulting from dissociation of $\mathbf{L} 4$ and/or $\mathrm{H}_{2} \mathrm{O}$. The new $\mathrm{Cp}^{*}$ resonances, that are shifted to higher field, should correspond to species with hydroxide groups, 
such as $\left[(\mathrm{Cp} * \mathrm{Rh})_{2}(\mu-\mathrm{OH})_{3}\right]^{+}[114]$ or $\left[(\mathrm{Cp} * \mathrm{Rh})_{2}(\mu-\mathrm{OH})_{2} \mathrm{Z}_{2}\right]^{\mathrm{n}+}\left(\mathrm{Z}=\mathrm{H}_{2} \mathrm{O}, \mathrm{Cl}\right)$ according to literature $[113,114]$.

With respect to the solution of $\mathbf{L} 4-\operatorname{Ir}(\mathbf{S})$ in DMSO- $d_{6}$, the addition of $\mathrm{D}_{2} \mathrm{O}$ leads to important changes in the ${ }^{1} \mathrm{H}$ NMR spectra. In the aromatic region, the disappearance of the L4-Ir(S) signals, together with the formation of $\mathbf{H L} 4$ and a new $\left[\mathrm{Cp}^{*} \operatorname{Ir}(\mathbf{L} 4)\left(\mathrm{H}_{2} \mathrm{O}\right)\right]^{+}$complex is observed (Figure S8). The amount of the aqua complex is reduced over time, while that of HL4 is increased. In the aliphatic region (Figure S9) two main resonances are observed which are assigned to the aqua complex and the hydroxo dimer $\left[\left(\mathrm{Cp}^{*} \mathrm{Ir}\right)_{2}(\mu-\mathrm{OH})_{3}\right]^{+}[120]$, whose amount increases with time. A small signal is also detected in the same position assigned to $\left[C \mathrm{p}^{*} \operatorname{Ir}(\mathrm{Z})_{3}\right]^{\mathrm{n}+}$ (see above).

Thus, for the three complexes, the aquation process takes place with the concomitant formation of HL4 and hydroxo derivatives, although in the case of L4-Rh a fast equilibrium is established amongst the different species in solution.

\subsection{UV-Vis Stability Studies of the Complexes with L4 in DMSO and Aqueous Solution}

The stability of the complexes containing L4 was performed by UV-Vis spectroscopy in DMSO observing that $\mathbf{L} 4-\mathbf{R} \mathbf{u}$ and $\mathbf{L} 4-\mathbf{R} \mathbf{h}$ present lower cleavage than its iridium analogue (See Figure S10). Additionally, the stability of the L4-M complexes was also studied by UV-Vis spectroscopy in the cacodylate $(\mathrm{NaCaC})$ aqueous buffer $\mathrm{pH}$ 7. Spectrograms compiled in Figure S11 exhibit isosbestic points indicative of different species in solution. The functions obtained from abs-time data pairs are biexponential and point to an aquation process along with ligand release, confirming NMR observations. From the comparison of the rate constants obtained at $\mathrm{pH}=7$ and at slightly acidic $\mathrm{pH}$ value $(\mathrm{pH}=5.5)$ it can be concluded that all L4-M complexes display less reactivity at $\mathrm{pH}=5.5$ than at $\mathrm{pH}=7$ (Figure S12).

\subsection{Determination of the $p K_{a}$ Values of $\mathbf{H L 4}, \mathbf{L 4 - R} \boldsymbol{u}, \mathbf{L 4}-\mathrm{R} \boldsymbol{h}$ and $\mathbf{L 4 - I r}$}

The acid-dissociation constants, $\mathrm{pK}_{\mathrm{a}}$, were determined by recording the absorbance spectra of the free pro-ligand HL4 and the L4-M complexes at different $\mathrm{pH}$ values, ranging from 3 to 11 in aqueous solution. Figure S13A shows the UV-vis absorbance spectra of HL4, and Figure S13B, C and D of L4-Ru, L4-Rh and L4-Ir, respectively. The absorbance-pH data pairs were examined and the $\mathrm{pK}_{\mathrm{a}}$ values compiled in Table 3. Data were analyzed according to the Henderson-Hasselbalch equation [121] for complexes L4-Ru, L4-Ir and HL4, or according to the Ang equation [122] for L4-Ir that displayed two determinable equilibria.

Table 3. $\mathrm{pK}_{\mathrm{a}}$ values obtained for HL4 and L4-M.

\begin{tabular}{cccc}
\hline Complex & pK $_{\mathbf{a}}$ & $\mathbf{p K}_{\mathrm{a} 1}$ & $\mathbf{p K}_{\mathrm{a} 2}$ \\
\hline L4-Ru & & $9.56 \pm 0.08$ & $>12$ \\
L4-Rh & & $9.67 \pm 0.03$ & $>11$ \\
L4-Ir & & $9.02 \pm 0.01$ & $11.41 \pm 0.04$ \\
HL4 & $8.59 \pm 0.04$ & & $>11$ \\
\hline
\end{tabular}

The ligand shows a single equilibrium $\left(\mathrm{pK}_{\mathrm{a}}=8.59\right)$ corresponding to the ionization of the chrysin hydroxyl group [123], but new bands observed at $\mathrm{pH}>11$ could be assigned to the $\mathrm{NH}^{+}$dissociation of the piperidinium group, because the $\mathrm{pK}_{\mathrm{a}}$ of the free piperidinium cation (protonated piperidine) is 11.22 [124]. Hence, under $\mathrm{pH}=7$, the proligand is mainly in the form of a monocation. By contrast, the spectrograms of $\mathbf{L} 4-\mathbf{M}$ complexes show two acid-base equilibria (Table 3), $\mathrm{pK}_{\mathrm{a} 1}$ and $\mathrm{pK}_{\mathrm{a} 2}$. In all cases, $\mathrm{pK}_{\mathrm{a} 1}$ corresponds to the proton dissociation of the coordinated water molecule to give the hydroxo complex [125,126]. According to these values, the acidity sequence of the coordinated $\mathrm{H}_{2} \mathrm{O}$ molecule is L4-Ir > L4-Ru > L4-Rh. Regarding $\mathrm{pK}_{\mathrm{a} 2}$, we propose that it corresponds to the dissociation of the piperidinium proton $\left(\mathrm{NH}^{+}\right)$. In fact, only the value of $\mathrm{pK}_{\mathrm{a} 2}$ for $\mathbf{L} 4-\mathrm{Ir}$ could be accurately determined. Nevertheless, inspection of the spectral curves and Abs-pH data-pairs of L4-Ru and L4-Rh (Figure S13B,C) reveals that a second acid-base equilibrium is feasible, 
with $\mathrm{pK}_{\mathrm{a} 2}>12$ and $\mathrm{pK}_{\mathrm{a} 2}>11$ for L4-Ru and L4-Rh, respectively (see Scheme 2). From these results, we can conclude that under $\mathrm{pH}=7$, the three compounds are dicationic $\mathrm{H}_{2} \mathrm{O}$-complexes, $\mathrm{N}$ is in the $\mathrm{NH}^{+}$form and the aqua form predominates over the hydroxo complex (form B in Scheme 2). An interesting aspect that derives from the protonation of the piperidine fragment is that it enhances the amphiphilic character of the neutral chlorido complexes ([ $\left.\left.\mathrm{LMCl}\left(\mathrm{O}^{\wedge} \mathrm{O}\right)\right]\right)$, since the positive charges are combined with hydrophobic motifs of the complexes such as the $p$-cymene or cyclopentadienyl rings and the alkyl groups of the cations.

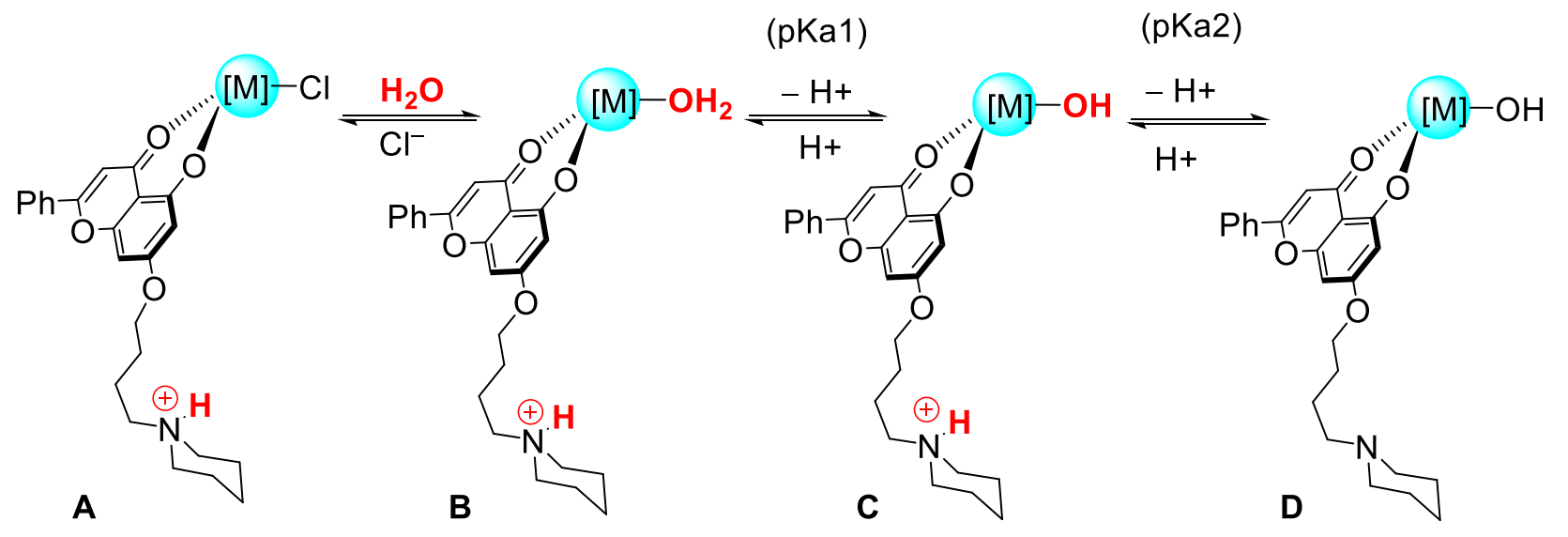

$[\mathrm{M}]=[p-\mathrm{cym}) \mathrm{Ru}],\left[\mathrm{Cp}{ }^{*} \mathrm{Rh}\right],\left[\mathrm{Cp}{ }^{*} \mathrm{Ir}\right]$

Scheme 2. Aquation reaction of $\mathbf{L} 4-\mathbf{M}$ complexes and deprotonation processes corresponding to $\mathrm{pK}_{\mathrm{a} 1}$ and $\mathrm{pK}_{\mathrm{a} 2}$.

\subsection{Interaction with DNA}

At this point, we can conclude that the identity of the chrysin derived ligands strongly influences the cytotoxicity of their metal complexes. Nonetheless, the role of the metal cannot be underestimated as far as stability and cytotoxic potential of the L4-complexes are concerned. DNA has been very often reported as the biological target for many metal complexes with anticancer activity $[127,128]$. Consequently, the interaction of the proligand HL4 or L4-complexes with CT-DNA was investigated by different techniques such as melting temperature $\left(\mathrm{T}_{\mathrm{m}}\right)$ and viscosity measurement, as well as circular dichroism and agarose gel electrophoresis studies.

\subsubsection{Thermal Denaturation by UV-Vis}

$\mathrm{T}_{\mathrm{m}}$ measurements were performed for fresh solutions in order to avoid decomposition processes. Figure $3 \mathrm{~A}$ to Figure $4 \mathrm{C}$ revealed a great increase in the melting temperature compared to free DNA, $\left(\Delta \mathrm{T}_{\mathrm{m}}=18{ }^{\circ} \mathrm{C}\right.$ for L4-Ru (Figure $5 \mathrm{~A}$ ), $\Delta \mathrm{T}_{\mathrm{m}}=17^{\circ} \mathrm{C}$ for $\mathbf{L} 4-\mathbf{R h}$ (Figure $5 \mathrm{~B}$ ) and $\Delta \mathrm{T}_{\mathrm{m}}>22{ }^{\circ} \mathrm{C}$ in the case of L4-Ir (Figure 5C)). Such an increase in the melting temperature is typical of intercalation processes. Thus, intercalation of the L4complexes between the DNA base pairs probably occurs through the ancillary ligand L4. Interestingly, only the cytotoxic proligand (see Table 1), HL4 (green line-Figure 6D) is able to thermally stabilize the DNA double helix with a similar efficiency than its complexes $\left(\Delta \mathrm{T}_{\mathrm{m}}=20^{\circ} \mathrm{C}\right)[123]$. 

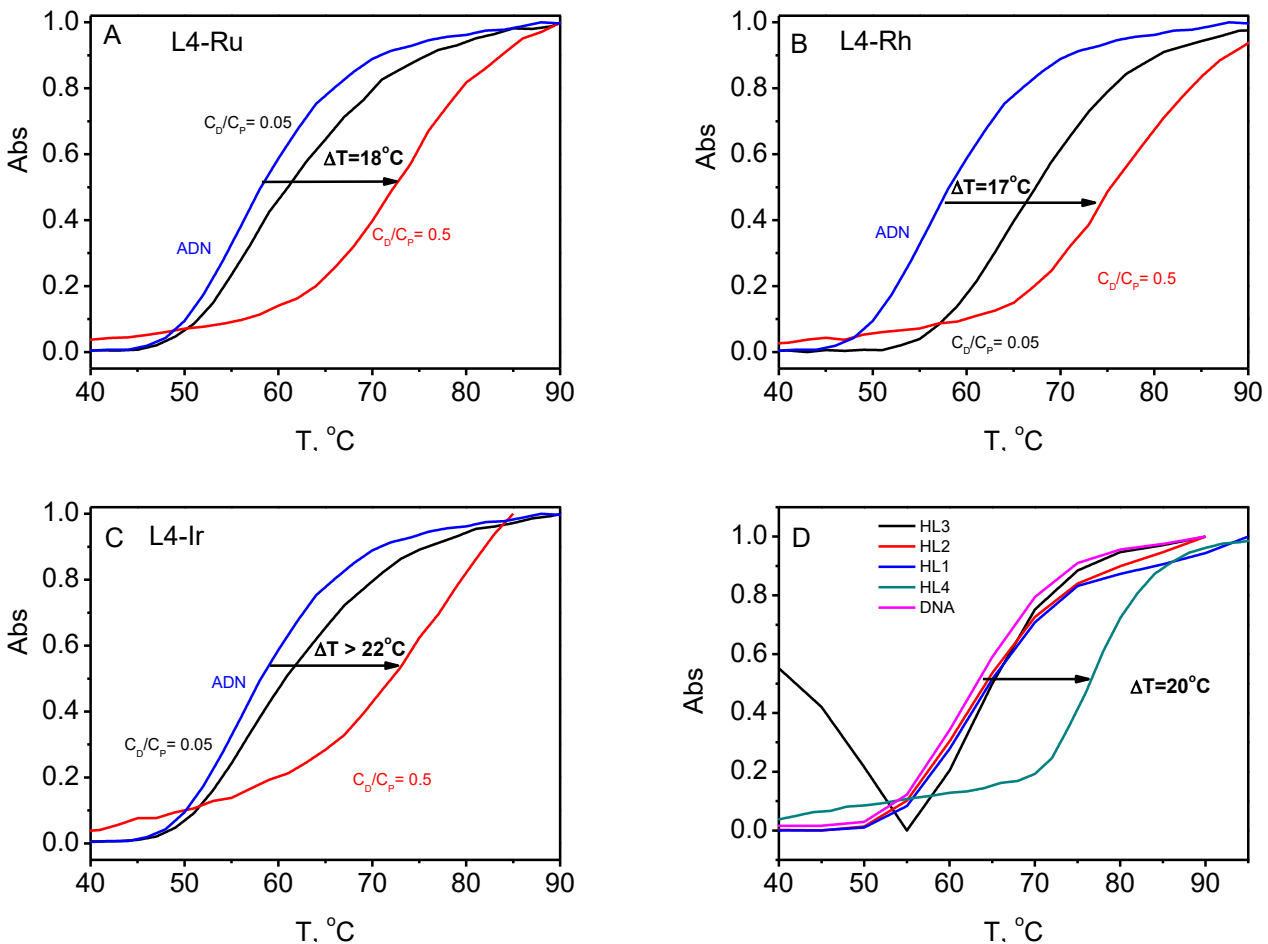

Figure 5. Melting profiles for (A) L4-Ru/DNA, (B) L4-Rh/DNA, (C) L4-Ir/DNA and (D) proligands HL1-HL4 with DNA at $C_{D} / C_{P}=0.5 . C_{P}=5.7 \times 10^{-5}$ M. $C_{D}=$ analytical concentration of the drug. $\mathrm{C}_{\mathrm{P}}=$ analytical concentration of DNA.
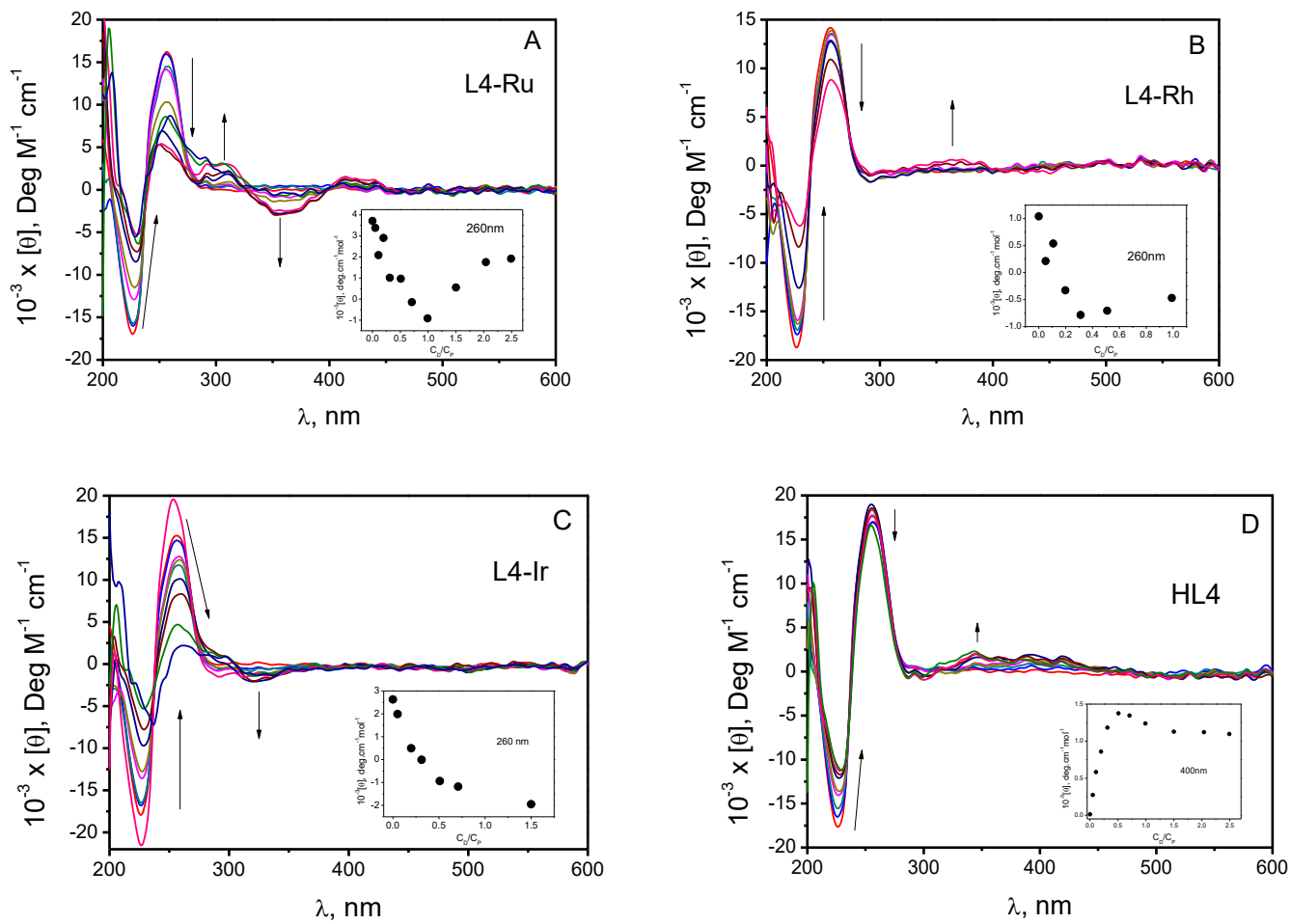

Figure 6. CD spectra for (A) L4-Ru/DNA, (B) L4-Rh/DNA, (C) L4-Ir/DNA and (D) HL4/DNA recorded with increasing drug concentration (arrow sense). $C_{P}=5.73 \times 10^{-5} \mathrm{M}, \mathrm{C}_{\mathrm{D}} / \mathrm{C}_{\mathrm{P}}=0-2.5$. Inset: dependence of the molar ellipticity at $260 \mathrm{~nm}$ on the $C_{D} / C_{P}$ ratio. 


\subsubsection{Circular Dichroism (CD)}

Dichroism experiments expose the conformational variation in DNA structure upon drug interaction. The CD titrations of DNA with increasing concentrations of HL4 and its three metal complexes were performed. Figure 6 reflects how each complex modifies the DNA spectrum in a different way.

The CD spectrum of the L4-Ru/DNA system showed that the molar ellipticity of both the negative and the positive bands of DNA decreased as the $C_{D} / C_{P}$ ratio rose (Figure $6 A$ ). Moreover, three induced circular dichroism bands (ICD) appeared with increasing $C_{D} / C_{P}$ values; namely, two positive bands centered at $300 \mathrm{~nm}$ and $360 \mathrm{~nm}$, and a negative one at $425 \mathrm{~nm}$, revealing the formation of new species. In a similar way, $\mathbf{L} 4-\mathbf{R h}$ induced a decrease in the molar ellipticity of the DNA intrinsic bands along with the appearance of a small ICD band at $380 \mathrm{~nm}$ (Figure 6B). In addition, L4-Ir caused a diminution of the intensity of the DNA intrinsic bands along with a red shift of $6 \mathrm{~nm}$ of the DNA positive band and the appearance of a new negative ICD band at $321 \mathrm{~nm}$ (Figure 6C). The proligand HL4 also induced a decrease in molar ellipticity of the DNA intrinsic CD bands and the appearance of a small ICD band (Figure 6D). These features in DNA titrations with HL4 and L4-M complexes are related to the unwinding of the DNA double helix as a consequence of the drug intercalation between the DNA base pairs [129].

\subsubsection{Viscosity}

Intercalation was corroborated by relative viscosity measurements (Figure 7). To enable the allocation of the drug in the intercalation site, DNA suffers a local unwinding which leads to DNA contour length enhancement. DNA saturation was observed at $C_{D} / C_{P}=0.1, C_{D} / C_{P}=0.3$ and $C_{D} / C_{P}=0.2$ for the L4-Ru/DNA, L4-Ir/DNA and HL4/DNA systems, respectively. For the L4-Rh/DNA system, a biphasic behavior was observed with a decrease in the DNA relative contour length up to $C_{D} / C_{P}=0.1$ followed by an increase from that point on (Figure 7B). Unfortunately, saturation was not observed for this system since precipitation occurs at high drug-DNA ratios $\left(C_{D} / C_{P}>0.5\right)$. The highest DNA contour length enhancement was observed for the HL4/DNA system. These data confirm the influence of both the ligand and the metal center on the intercalation process [129].
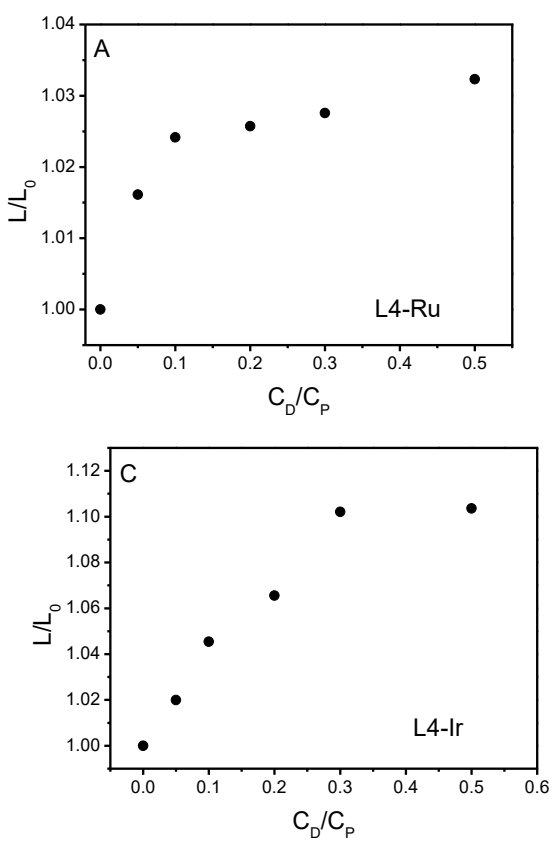
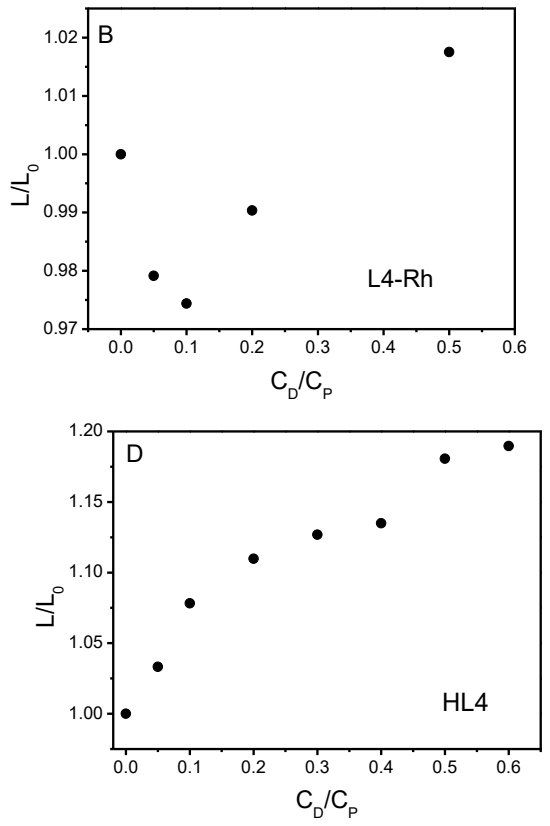

Figure 7. DNA relative contour length $\left(\mathrm{L} / \mathrm{L}_{0}\right)$ for (A) L4-Ru/DNA, (B) L4-Rh/DNA, (C) L4-Ir/DNA and (D) HL4/DNA systems as a function of the $C_{D} / C_{P}$ ratio. $C_{P}{ }^{0}=2.0 \times 10^{-4} \mathrm{M}$. 


\subsubsection{Agarose Gel Electrophoresis}

The electrophoretic mobility of the plasmid DNA pUC18 in the absence and in the presence of HL4 and its metal complexes was studied (Figure 8) to enlighten the features of the interaction between DNA and the compound under study. The differences observed in the migration pattern between the plasmid alone (lane 1) or treated with the vehicle, DMSO (lane 2), and the plasmid incubated with different concentrations of HL4 and L4-M confirmed DNA binding. It is clear that the amount of DMSO used in the experiments does not affect the migration pattern of the plasmid. On the other hand, the experiment with cisplatin (lane 3) which was included as a positive control for covalent binding, showed higher mobility of open circular (OC) and supercoiled (SC) forms than those observed for the free plasmid. In the experiments performed with plasmids treated with L4-Ru (lanes 4-6) and L4-Rh (lanes 7-9), the SC form migrates slower than in the assay with free plasmid and this retardation is dose-dependent. This behavior can be easily related to intercalation processes [130]. A vanishing of the plasmid bands at high drug-DNA concentrations ratio was observed for the L4-Rh/pUC18 system. This may occur due to plasmid saturation with the rhodium complex that prevents ethidium bromide staining, or due to precipitation of the large amount of the rhodium complex bound to DNA. The amount of the OC form is significantly increased in the presence of L4-Ir (lines 10-12), in contrast with its analogues. Thus, the iridium complex efficiently cleaved supercoiled DNA and this cleavage will be further studied. As expected, HL4 shows a different trend in SC migration with respect to its complexes, which reinforces the hypothesis that the metal center plays a key role in the interaction with DNA [129].

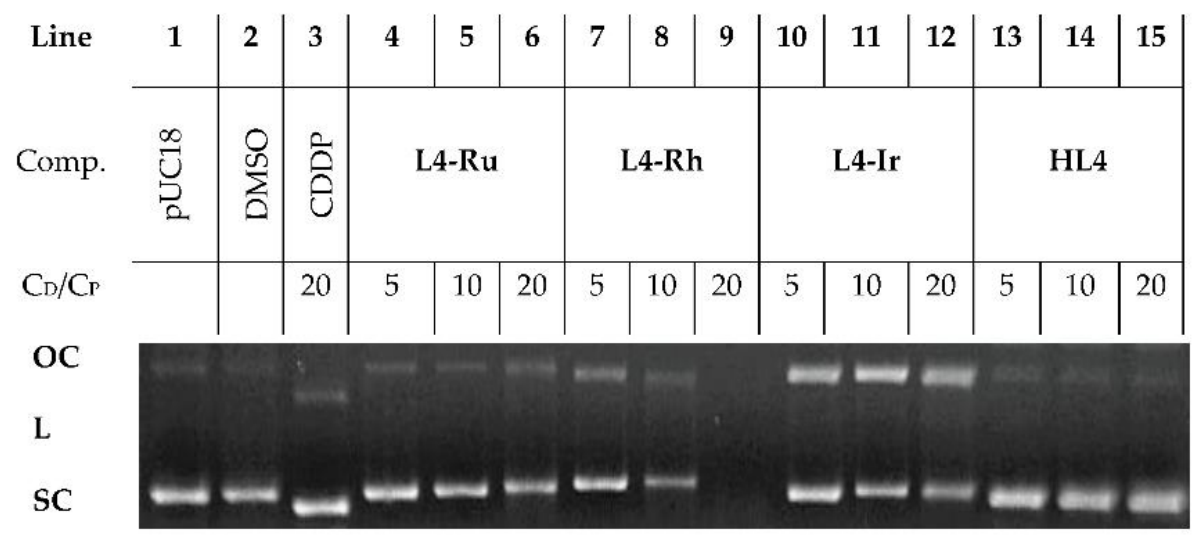

Figure 8. Electrophoresis mobility assay of pUC18 $(20 \mu \mathrm{M})$ with DMSO (lane 2), cisplatin (lane 3), L4-Ru (lanes 4-6), L4-Rh (lanes 7-9), L4-Ir (lanes 10-12) and HL4 (lanes 13-15) at different $C_{D} / C_{P}$ ratios. SC: supercoiled, OC: open circular and L: linear forms.

Since only the iridium complex display DNA chemical nuclease activity, the underlying mechanism was further investigated by means of a cleavage electrophoresis assay in which several well-known radical scavengers such as DMSO for $\mathrm{OH}$, L-histidine for ${ }^{1} \mathrm{O}_{2}$, sodium pyruvate for $\mathrm{H}_{2} \mathrm{O}_{2}$ and superoxide dismutase (SOD) for $\mathrm{O}_{2}{ }^{-}$were included (Figure 9) [129]. Treatment of pUC18 with a high concentration of L4-Ir (lane 14) causes the vanishing of the $\mathrm{SC}$ form and an increase in the amount of the $\mathrm{OC}$ and $\mathrm{L}$ topologies. In the presence of different amounts of DMSO (lanes 2 and 3) or pyruvate (lanes 8 and 9), DNA cleavage is not inhibited, whereas SOD (lanes 11 and 12) seems to partially circumvent the cleavage activity of L4-Ir. However, L-histidine efficiently inhibits the cleavage activity of L4-Ir (lanes 5 and 6), even at the lowest concentration. Therefore, ${ }^{1} \mathrm{O}_{2}$ turns out to be the reactive oxygen species responsible for the DNA damage induced by L4-Ir. At this point, the metal center seems to be the key, since although HL4 and L4-M complexes are able to interact with DNA only the iridium derivative cleaves DNA by an $\mathrm{O}_{2}$ dependent mechanism. The ability of L4-Ir to generate singlet oxygen constitutes an important advantage for its potential as antitumor agent over its analogues, since singlet oxygen is identified as 
one of the major ROS produced in mitochondria and altering its levels is reported as an efficient strategy for cancer therapy [131].

\begin{tabular}{c|c|c|c|c|c|c|c|c|c|c|c|c|c|c} 
Lane & $\mathbf{1}$ & $\mathbf{2}$ & $\mathbf{3}$ & $\mathbf{4}$ & $\mathbf{5}$ & $\mathbf{6}$ & $\mathbf{7}$ & $\mathbf{8}$ & $\mathbf{9}$ & $\mathbf{1 0}$ & $\mathbf{1 1}$ & $\mathbf{1 2}$ & $\mathbf{1 3}$ & $\mathbf{1 4}$ \\
\hline & \multicolumn{3}{|c|}{ DMSO, M } & \multicolumn{2}{|c|}{ L-His, mM } & \multicolumn{3}{c}{$\begin{array}{c}\text { Pyruvate, } \\
\mathrm{mM}\end{array}$} & \multicolumn{3}{|c}{ SOD, U } & & \multicolumn{3}{c}{} \\
\hline & 2 & 0.4 & 2 & 12 & 1.2 & 12 & 10 & 2.5 & 10 & 120 & 15 & 120 & & - \\
\hline $\begin{array}{c}\text { L4- } \\
\text { Ir, } \\
\mathbf{\mu M}\end{array}$ & 0 & 238 & 238 & 0 & 238 & 238 & 0 & 238 & 238 & 0 & 238 & 238 & 0 & 238 \\
\hline
\end{tabular}

Figure 9. Cleavage electrophoresis of pUC18 $(20 \mu \mathrm{M})$ incubated with L4-Ir or/and with DMSO ( $0.4 \mathrm{M}$ and $2 \mathrm{M})$, L- histidine (1.2 $\mathrm{mM}$ and $12 \mathrm{mM})$, sodium pyruvate $(2.5 \mathrm{mM}$ and $10 \mathrm{mM}$ ) or SOD (15 U and $120 \mathrm{U}$ ). Lane 13 is the control for pUC18 alone, and lane 14 is pUC18 with L4-Ir.

\subsection{Intracellular ROS Generation}

Since cytotoxicity is often related to ROS generation in $\mathrm{Ru}(\mathrm{II})[40,132,133]$ and $\operatorname{Ir}(\mathrm{III})[133,134]$ half-sandwich complexes, the ability of HL4 and its metal complexes to induce ROS generation in lung adenocarcinoma (A549) cells was studied by flow cytometry (FC) using $\mathrm{H}_{2}$ DCFDA (dihydrodichlorofluorescein diacetate) as a probe for hydrogen peroxide, nitric oxide and peroxynitrite among other ROS [135]. More deeply, the oxidation of non-fluorescent $\mathrm{H}_{2}$ DCFDA to highly fluorescent DCF $\left(2^{\prime}, 7^{\prime}\right.$ diclorofluorescein) by ROS produced inside the cells is monitored by FC. From the results compiled in Figure 10, we concluded that, unlike HL4, all its metal complexes increase ROS production, with the Ir complex inducing the greatest effect. ROS levels can be modulated by several reported mechanisms such as binding of the metal complex to GSH, thioredoxin reductase inhibition, catalytic oxidation of NADH and NADPH $[36,136,137]$.

\subsection{Apoptosis}

ROS generation leads to oxidative stress and can trigger apoptosis. In order to confirm if apoptosis is the mechanism of cell death caused by the compounds under study, apoptosis induction was studied by flow cytometry. As revealed by the respective FC plots (Figure 11), the population of cells in necrosis, late and early apoptosis are significantly increased upon treatment with metal complexes. By contrast, treatment with the ligand only induces apoptosis. These results suggest that the oxidative stress caused upon exposure to our metal complexes is moderate since apoptosis is the preferred pathway for cell death. On the other hand, the differences observed in the ability to induce ROS generation among the metal complexes may be correlated to the percentage of necrotic cells. That is, Ir-L4 exhibits both the greatest ROS production and the biggest population of necrotic cells pointing out to a higher level of oxidative stress than that observed after the treatment with the Ru or $\mathrm{Rh}$ analogues. 

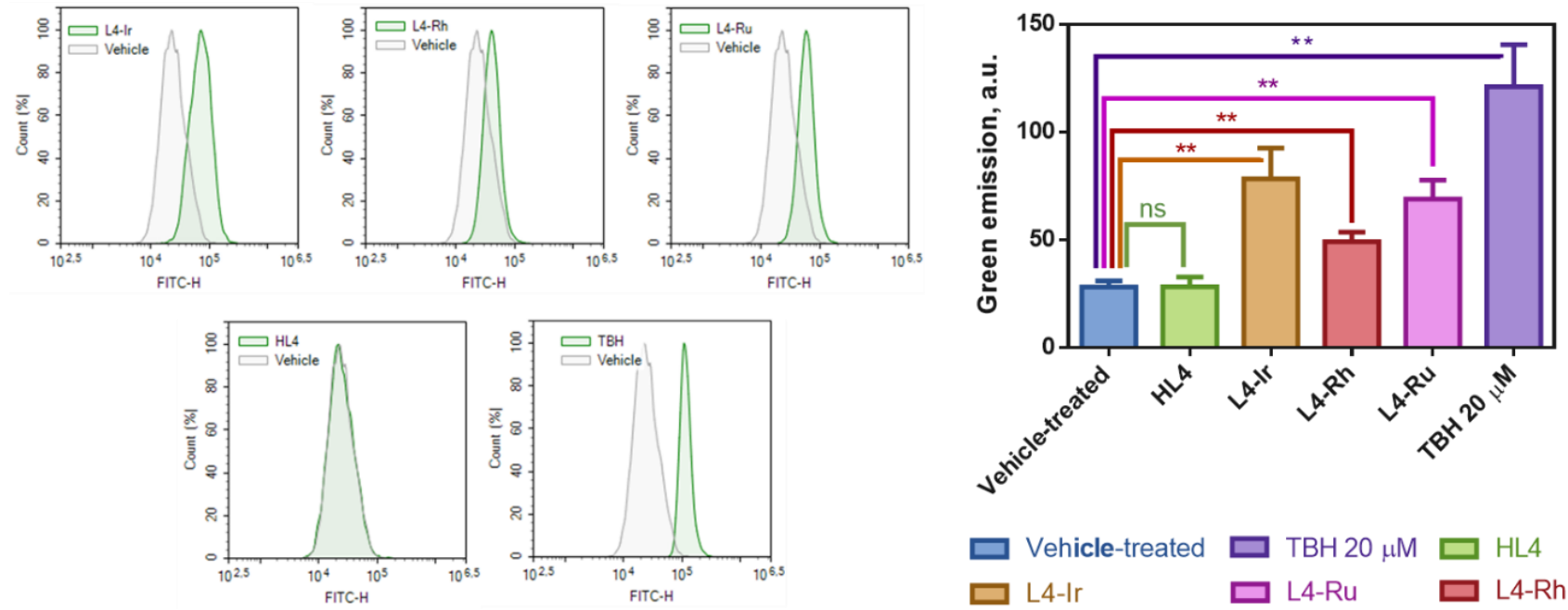

Figure 10. Flow cytometry plots of A549 cells treated with HL4, L4-Ir, L4-Rh, L4-Ru at their IC 50 values during 24 h. Cells treated with $20 \mu \mathrm{M}$ of TBH (tert-butyl-hydroperoxide) were included as positive control for $\mathrm{H}_{2} \mathrm{O}_{2}$ generation. Results are expressed as the mean $\pm \mathrm{SD}$ and statistical significance is expressed as ${ }^{* *}$, $p$-value $<0.01$ (ANOVA-Dunnett).
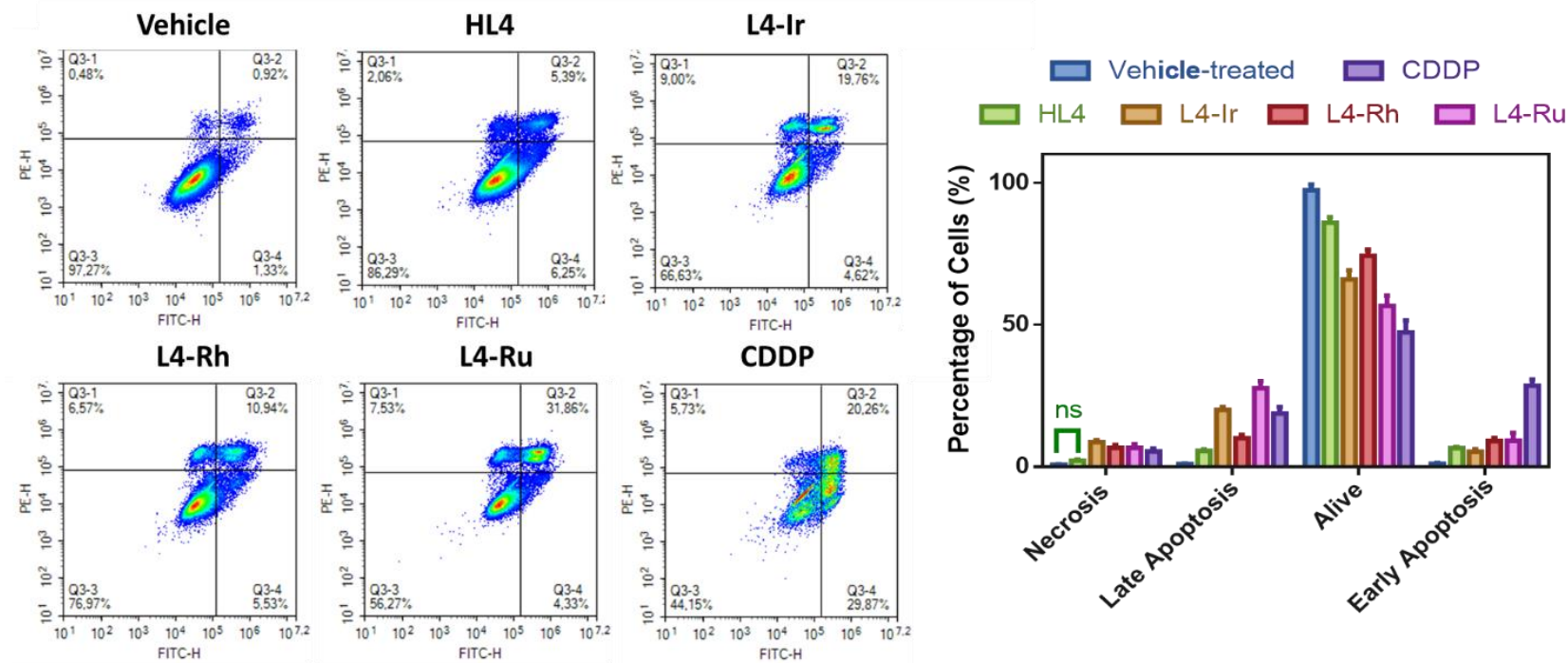

Figure 11. Examples of FC density plots of apoptosis studies in A549 cells treated with HL4, L4-Ir, L4-Rh, L4-Ru and CDDP at their $\mathrm{IC}_{50}$ values during $24 \mathrm{~h}$ and staining with annexin V-FITC/PI. The results are expressed as the mean $\pm \mathrm{SD}$ of at least two different experiments with two replicates. The values achieved are statistically significant results $(p$-value $<0.01-$ ANOVA-Dunnett) except if no significance (ns) is stated.

\subsection{Cell Cycle Studies}

Cell cycle arrest brings more opportunities for cells to enter apoptosis which is a desirable effect in chemotherapeutic drugs. Cell cycle progression in A549 cells exposed to HL4 and their metal complexes for $24 \mathrm{~h}$ was studied by flow cytometry. In short, treatment with HL4 does not induce cell cycle arrest, whereas treatment with the metal complexes induces cell cycle arrest in G0/G1 along with a drop in S and G2/M populations (Figure 12). Cell cycle arrest in G0/G1 is a common feature in cells treated with ROS generating chemotherapeutic agents. 


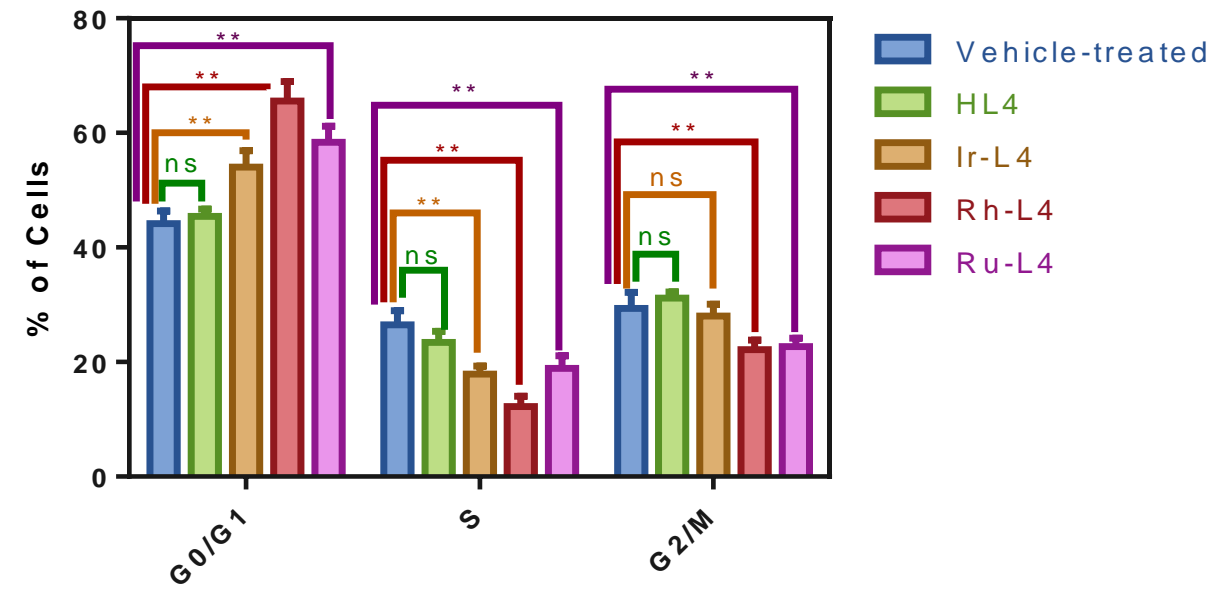

Figure 12. Flow cytometry analysis of cell cycle distribution of A549 cells treated during $24 \mathrm{~h}$ with the compounds under study. Data were obtained from duplicates of two different experiments and plot as mean values \pm SD. ns No significance and ${ }^{* *}$ Statistical significance, $p$-value $<0.01$ (ANOVA-Dunnett).

\subsection{Cellular Uptake}

In addition to differences in biological behavior, such as the generation of ROS, the differences in the cytotoxicity amongst different compounds may also be related to their success in getting into cells. Hence, inductively coupled plasma mass spectrometry (ICPMS) was employed to quantify the amount of metal inside A549 cells treated with the L4complexes during $24 \mathrm{~h}$ (Figure 13) [129]. The accumulation of all the complexes was higher than that determined for cisplatin. There is no correlation between metal internalization and cytotoxic activity in A549 cells. In fact, the most cytotoxic complex (L4-Ir) turned out to be the one with the lowest cellular uptake, which supports the hypothesis of a dual mechanism of action. DNA binding and ROS formation provide this complex with a great effectivity in terms of cytotoxicity in spite of its low accumulation inside the cells. Moreover, although the cellular uptake of $\mathbf{L} 4-\mathbf{R h}$ is quite higher than that of $\mathbf{L} 4-\mathbf{R u}$, their cytotoxic activities are very similar, with no notable differences in terms of DNA interaction. In order to explain this lack of correlation, the potential sequestration of L4-M complexes by serum proteins (BSA) was analyzed in the next section.

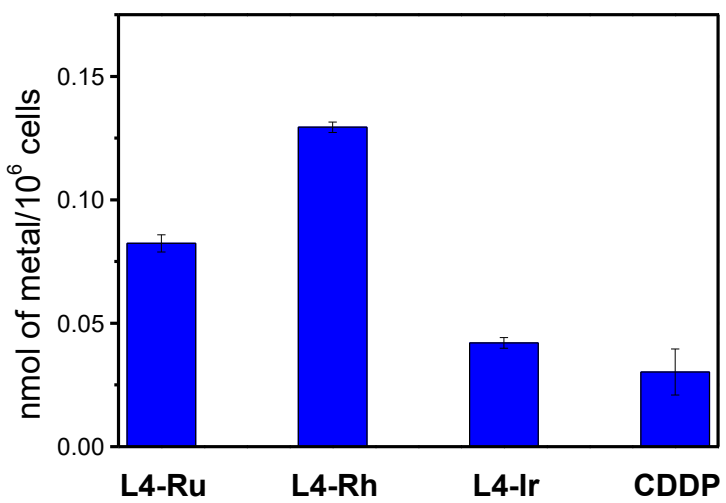

Figure 13. Metal accumulation in A549 cells after $24 \mathrm{~h}$ of treatment with $5 \mu \mathrm{M}$ of the compounds under study. Cisplatin is included for comparison.

\subsection{Interaction with $B S A$}

Protein binding was found to be a determining factor in the tumor accumulation of some new metal complexes and consequently, in their anticancer activity [138]. By contrast, is has also been described that binding to serum proteins may be a limiting factor for cytotoxicity since serum proteins can sequestrate metal complexes preventing their access 
to their target and limiting their cytotoxicity [139]. With this in mind, we have studied the interaction of the L4-M complexes with bovine serum album (BSA) due to its high similarity to human serum albumin (HSA, one of the most abundant proteins present in blood plasma) by native acrylamide gel electrophoresis [129]. Figure 14 shows BSA migration after being incubated with the complexes in the dark for $24 \mathrm{~h}$ at two different drug-BSA ratios: 10 and 20. Negative controls of BSA alone (lanes 7 and 8) or vehicle-DMSO (BSA in the presence of the maximum DMSO concentration used in the experiment, lanes 9 and 10) are included. Complex L4-Ru is not able to induce conformational changes in BSA (lanes 1 and 2). Complex L4-Rh alters BSA structurally only at higher concentrations $C_{D} / C_{P}=20$ (lane 4). These results do not explain the differences in the cellular uptake of $\mathrm{Ru}$ and $\mathrm{Rh}$ derivatives. Noteworthy, L4-Ir, which is the most cytotoxic complex, affects the protein conformation in a stronger way than its congeners (lanes 5 and 6). Circular Dichroism experiments of BSA in presence of HL4 or its metal complexes confirm the electrophoresis conclusions. Figure S14 shows higher interaction of BSA with L4-Ir compared to L4-Rh and L4-Ru. This fact can be easily correlated with the low accumulation of L4-Ir inside the cells due to its partial sequestration by serum proteins.

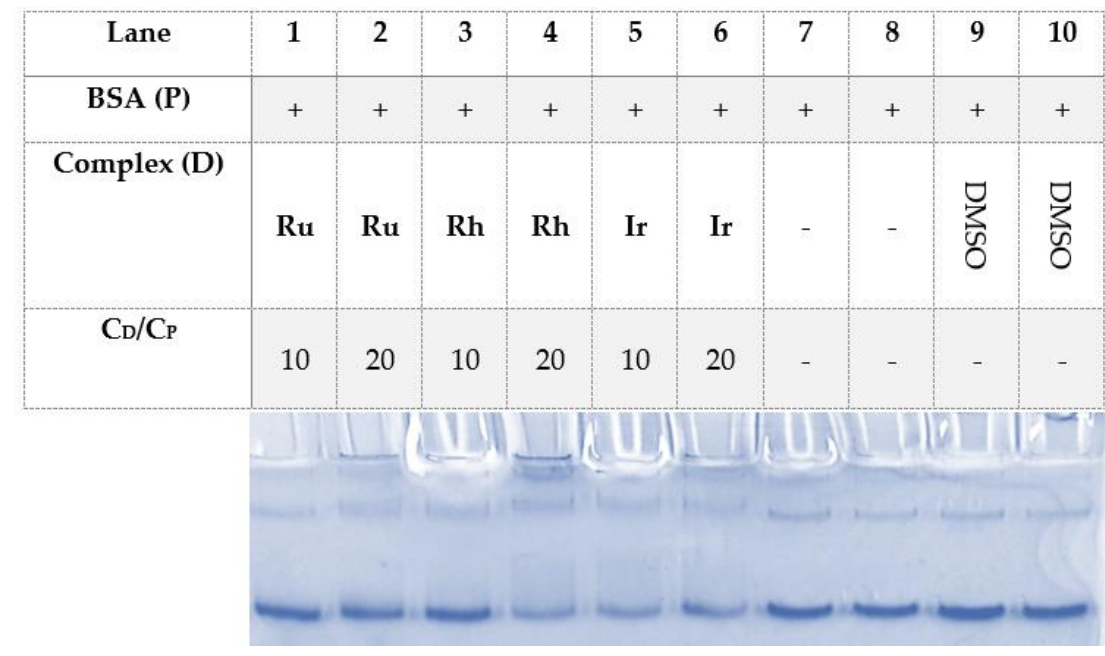

Figure 14. Native PAGE electrophoresis of BSA incubated during $24 \mathrm{~h}$ with different concentrations of the L4-M complexes. $C_{P}=1.5 \mu \mathrm{M} . \mathrm{C}_{\mathrm{D}} / \mathrm{C}_{\mathrm{P}}=10$ and 20. $\mathrm{C}_{\mathrm{P}}=\mathrm{BSA}$ concentration; $\mathrm{C}_{\mathrm{D}}=$ complexes concentration.

\section{Conclusions}

With the aim of obtaining multitargeted metallodrugs including a bioactive ligand, a family of 12 half sandwich iridium, rhodium and ruthenium complexes with a series of chrysin-derived ligands L1-L4 containing different substituents have been synthesized and characterized. The antiproliferative activity of proligands HL1-HL4 and their complexes was tested on SW480 and A549 cell lines and clear effects attributed to the metal center and the ligand were found. The most active species in both cell lines were the piperidine proligand HL4 and its metal complexes L4-M, with the following cytotoxic potency order L4-Ir $>\mathbf{L} 4-\mathbf{R u} \approx \mathbf{L} 4-\mathbf{R h}$. All of them had a cytotoxic effect higher than cisplatin. Furthermore, L4-M complexes exhibited more selectivity towards cancer cells than HL4 and cisplatin. HL4 and L4-M were able to circumvent resistance in cisplatin resistant ovarian cancer cells (A2780cis). From the measurements of the $\mathrm{pK}_{\mathrm{a}}$ values, it is concluded that the piperidine fragment is protonated under biological conditions, a fact that may increase the amphiphilic character of the neutral chlorido-complexes of formula [ $\left.\mathrm{LMCl}\left(\mathrm{O}^{\wedge} \mathrm{O}\right)\right]$.

The cellular uptake of the piperidine containing-complexes was evaluated and the following order was found: L4-Rh $>$ L4-Ru > L4-Ir. The low accumulation of L4-Ir was explained by the interaction with BSA that reflects a partial sequestration by the blood serum proteins. 
The ligand HL4 and its L4-M complexes are able to interact with double stranded DNA by intercalation, which was confirmed by $C D$, melting and viscosity experiments. Besides, complex L4-Ir exhibited DNA chemical nuclease activity through the generation of ROS (Reactive Oxygen Species), more specifically, ${ }^{1} \mathrm{O}_{2}$. This supports the hypothesis of a dual mechanism of action and provides this complex with a great effectiveness in terms of cytotoxicity, in spite of its low accumulation inside the cells.

Evidence of the different biological behavior of the proligand HL4 respecting its L4-M complexes were clearly observed "in cellula" experiments. The metal complexes were able to induce ROS generation and block cell cycle progression in G0/G1 phase, whereas no effect was observed for the proligand. In any case, all the piperidine derivatives triggered apoptosis.

An important conclusion of this work is the significant effect that the introduction of the piperidine fragment in the ligand had on the antiproliferative behavior of the metal complexes, a fact that could be applied for future research, even using known metallodrugs.

Supplementary Materials: The following are available online at https:/ / www.mdpi.com/article / $10.3390 /$ pharmaceutics $13101540 / \mathrm{s} 1$. Synthesis and characterization of the new complexes: ${ }^{1} \mathrm{H}$ and ${ }^{13} \mathrm{C}\left\{{ }^{1} \mathrm{H}\right\}$ NMR spectra of HL1-HL4 and M-L $(\mathrm{M}=\mathrm{Ru}, \mathrm{Rh}, \mathrm{Ir} ; \mathrm{L}=\mathrm{L} 1, \mathrm{~L} 2, \mathrm{~L} 3, \mathrm{~L} 4)$, Table S1: ${ }^{1} \mathrm{H}$ NMR data for the chrysin-derived ligands in the $\mathbf{L}-\mathbf{M}(\mathrm{L}=\mathrm{L} 1-\mathrm{L} 4$ and $\mathrm{M}=\mathrm{Ru}, \mathrm{Rh}, \mathrm{Ir})$ complexes in $\mathrm{CDCl}_{3}$, Table S2: Crystal data and structure refinement for HL2, Table S3: Bond lengths [ $\AA$ ] and angles [ ${ }^{\circ}$ ] for HL2, Figure S1: dimers formed in proligand HL2 by formation of double head-to-tail hydrogen bonds, Table S4: Data for the hydrogen bonds formed in HL2, Figure S2: Aromatic area of ${ }^{1} \mathrm{H}$ NMR spectra of L4-Ru in DMSO- $d_{6}(400 \mathrm{MHz})$, Figure S3: Aromatic area of ${ }^{1} \mathrm{H}$ NMR spectra of $\mathbf{L} 4-\mathbf{R h}$ in DMSO- $d_{6}(400 \mathrm{MHz})$, Figure S4: Aromatic area of ${ }^{1} \mathrm{H}$ NMR spectra of L4-Ir in DMSO- $d_{6}(400 \mathrm{MHz})$, Figure S5: Aliphatic area of ${ }^{1} \mathrm{H}$ NMR spectra of L4-Ru in DMSO- $d_{6}: \mathrm{D}_{2} \mathrm{O}(3: 2)(400 \mathrm{MHz})$, Figure S6: Aromatic area of ${ }^{1} \mathrm{H}$ NMR spectra of L4-Rh in DMSO- $d_{6}: \mathrm{D}_{2} \mathrm{O}(3: 2)$ (400 MHz), Figure S7: Aliphatic area of ${ }^{1} \mathrm{H}$ NMR spectra of $\mathbf{L} 4-\mathbf{R} \mathbf{h}$ in DMSO- $d_{6}: \mathrm{D}_{2} \mathrm{O}(3: 2)(400 \mathrm{MHz})$, Figure S8: Aromatic area of ${ }^{1} \mathrm{H}$ NMR spectra of L4-Ir in DMSO- $d_{6}: \mathrm{D}_{2} \mathrm{O}(3: 2)(400 \mathrm{MHz})$, Figure S9: Aliphatic area of ${ }^{1} \mathrm{H}$ NMR spectra of L4-Ir in DMSO- $d_{6}: \mathrm{D}_{2} \mathrm{O}(3: 2)$ (400 MHz), Figure S10: Absorbance spectra over time of (A) L4-Ru, (B) L4-Rh, (C) L4-Ir, in DMSO. CD = $1.66 \times 10^{-5} \mathrm{M}$, Figure S11: Absorbance spectra over time in buffer solution of (A) L4-Ru, (B) L4-Rh and (C) L4-Ir. CD $=3.30 \times 10^{-5} \mathrm{M}$, Figure S12: Kinetic traces and biexponential fitting results of $\mathbf{L} 4-\mathbf{R u}, \mathbf{L} 4-\mathbf{R h}$ and $\mathbf{L} 4-\mathbf{I r}$ in buffer solution at $\mathrm{pH}=5.5$ and $\mathrm{pH}=7$, Figure S13: Absorbance spectra of (A) HL4, (B) L4-Ru, (C) L4-Rh, (D) L4-Ir, recorded in the pH 3-11 range. Inset: $\mathrm{pH}$ effect on the complexes absorbance at (A) $268 \mathrm{~nm}$, (B) $267 \mathrm{~nm}$, (C) $262 \mathrm{~nm}$, (D) 385 $\mathrm{nm}$. $\mathrm{CD}=3.3 \times 10^{-5} \mathrm{M}$, Figure S14: CD spectra of BSA in the absence and in the presence of the L4-M complexes $(\mathrm{M}=\mathrm{Ru}, \mathrm{Rh}$ and $\mathrm{Ir})$ at a [L4-M]/[BSA] concentration ratio of 5 . CBSA $=0.5 \mu \mathrm{M}$, $\mathrm{CDMSO}=0.002 \%, \mathrm{I}=2.5 \mathrm{mM}$ sodium cacodylate $(\mathrm{NaCac}), \mathrm{pH}=7.4$ and $\mathrm{T}=25^{\circ} \mathrm{C}$.

Author Contributions: Conceptualization, G.E.; Methodology, N.B., B.G., F.A.J. and B.R.M.; Validation, G.E., N.B., B.G and B.R.M.; Formal Analysis, N.B.; Investigation, A.R.R.; R.G., N.B., M.V., A.L.I. and A.M.R.; Resources, B.G. and F.A.J.; Writing-Original Draft Preparation, A.R.R., N.B., M.V. and B.R.M.; Writing-Review \& Editing, N.B.; B.G., G.E., F.A.J. and B.R.M.; Supervision, B.R.M., B.G., F.A.J. and N.B,; Funding Acquisition, B.G., F.A.J., G.E., N.B. and B.R.M. All authors have read and agreed to the published version of the manuscript.

Funding: This research was funded by the Spanish Ministerio de Ciencia, Innovación y UniversidadesFEDER (RTI2018-100709-B-C21 and RTI2018-102040-B-100), Junta de Comunidades de CastillaLa Mancha-FEDER (JCCM) (grant SBPLY/19/180501/000260), Junta de Castilla y León-FEDER (BU087G19 and BU305P18), "la Caixa" Foundation (LCF/PR/PR12/11070003), as well as by UCLMFEDER (grants 2019-GRIN-27183 and 2019-GRIN-27209).

Institutional Review Board Statement: Not applicable.

Informed Consent Statement: Not applicable.

Data Availability Statement: The data presented in this study are available on request from the corresponding author.

Conflicts of Interest: The authors declare no conflict of interest. 


\section{References}

1. Heffeter, P.; Jungwirth, U.; Jakupec, M.; Hartinger, C.; Galanski, M.; Elbling, L.; Micksche, M.; Keppler, B.; Berger, W. Resistance against novel anticancer metal compounds: Differences and similarities. Drug Resist. Updates 2008, 11, 1-16. [CrossRef]

2. Van Rijt, S.H.; Sadler, P.J. Current applications and future potential for bioinorganic chemistry in the development of anticancer drugs. Drug Discov. Today 2009, 14, 1089-1097. [CrossRef] [PubMed]

3. Medici, S.; Peana, M.; Nurchi, V.M.; Lachowicz, J.I.; Crisponi, G.; Zoroddu, M.A. Noble metals in medicine: Latest advances. Coord. Chem. Rev. 2015, 284, 329-350. [CrossRef]

4. Hartinger, C.G.; Dyson, P. Bioorganometallic chemistry-From teaching paradigms to medicinal applications. Chem. Soc. Rev. 2009, 38, 391-401. [CrossRef] [PubMed]

5. Zhang, P.; Sadler, P.J. Advances in the design of organometallic anticancer complexes. J. Organomet. Chem. 2017, 839, 5-14. [CrossRef]

6. Gasser, G.; Ott, I.; Metzler-Nolte, N. Organometallic Anticancer Compounds. J. Med. Chem. 2010, 54, 3-25. [CrossRef]

7. Hartinger, C.G.; Metzler-Nolte, N.; Dyson, P.J. Challenges and Opportunities in the Development of Organometallic Anticancer Drugs. Organometallics 2012, 31, 5677-5685. [CrossRef]

8. Thota, S.; Rodrigues, D.A.; Crans, D.; Barreiro, E.J. Ru(II) Compounds: Next-Generation Anticancer Metallotherapeutics? J. Med. Chem. 2018, 61, 5805-5821. [CrossRef]

9. Jakupec, M.A.; Galanski, M.; Arion, V.B.; Hartinger, C.; Keppler, B. Antitumour metal compounds: More than theme and variations. Dalton Trans. 2008, 183-194. [CrossRef]

10. Tremlett, W.D.; Goodman, D.M.; Steel, T.R.; Kumar, S.; Wieczorek-Błauż, A.; Walsh, F.P.; Sullivan, M.P.; Hanif, M.; Hartinger, C.G. Design concepts of half-sandwich organoruthenium anticancer agents based on bidentate bioactive ligands. Coord. Chem. Rev. 2021, 445, 213950. [CrossRef]

11. Sun, Q.; Li, Y.; Shi, H.; Wang, Y.; Zhang, J.; Zhang, Q. Ruthenium Complexes as Promising Candidates against Lung Cancer. Molecules 2021, 26, 4389. [CrossRef] [PubMed]

12. Elsayed, S.A.; Harrypersad, S.; Sahyon, H.A.; Abu El-Magd, M.; Walsby, C.J. Ruthenium(II)/(III) DMSO-Based Complexes of 2-Aminophenyl Benzimidazole with In Vitro and In Vivo Anticancer Activity. Molecules 2020, 25, 4284. [CrossRef] [PubMed]

13. Simović, A.R.; Masnikosa, R.; Bratsos, I.; Alessio, E. Chemistry and reactivity of ruthenium(II) complexes: DNA/protein binding mode and anticancer activity are related to the complex structure. Coord. Chem. Rev. 2019, 398, 113011. [CrossRef]

14. Omondi, R.O.; Ojwach, S.O.; Jaganyi, D. Review of comparative studies of cytotoxic activities of Pt(II), Pd(II), Ru(II)/(III) and $\mathrm{Au}(\mathrm{III})$ complexes, their kinetics of ligand substitution reactions and DNA/BSA interactions. Inorg. Chim. Acta 2020, $512,119883$. [CrossRef]

15. Allardyce, C.S.; Dyson, P.J. Ruthenium in medicine: Current clinical uses and future prospects. Platin. Met. Rev. 2001, 45, 62-69.

16. Clarke, M.J. Ruthenium metallopharmaceuticals. Coord. Chem. Rev. 2002, 232, 69-93. [CrossRef]

17. Kenny, R.G.; Marmion, C.J. Toward Multi-Targeted Platinum and Ruthenium Drugs-A New Paradigm in Cancer Drug Treatment Regimens? Chem. Rev. 2019, 119, 1058-1137. [CrossRef] [PubMed]

18. Zeng, L.; Gupta, P.; Chen, Y.; Wang, E.; Ji, L.; Chao, H.; Chen, Z.-S. The development of anticancer ruthenium(II) complexes: From single molecule compounds to nanomaterials. Chem. Soc. Rev. 2017, 46, 5771-5804. [CrossRef]

19. Kostova, I. Ruthenium Complexes as Anticancer Agents. Curr. Med. Chem. 2006, 13, 1085-1107. [CrossRef]

20. Alessio, E.; Mestroni, G.; Bergamo, A.; Sava, G. Ruthenium Antimetastatic Agents. Curr. Top. Med. Chem. 2004, 4, 1525-1535. [CrossRef]

21. Bergamo, A.; Gaiddon, C.; Schellens, J.; Beijnen, J.; Sava, G. Approaching tumour therapy beyond platinum drugs: Status of the art and perspectives of ruthenium drug candidates. J. Inorg. Biochem. 2012, 106, 90-99. [CrossRef]

22. Steel, T.R.; Walsh, F.; Wieczorek-Błauż, A.; Hanif, M.; Hartinger, C.G. Monodentately-coordinated bioactive moieties in multimodal half-sandwich organoruthenium anticancer agents. Coord. Chem. Rev. 2021, 439, 213890. [CrossRef]

23. Alessio, E. Thirty Years of the Drug Candidate NAMI-A and the Myths in the Field of Ruthenium Anticancer Compounds: A Personal Perspective. Eur. J. Inorg. Chem. 2016, 2017, 1549-1560. [CrossRef]

24. Hartinger, C.G.; Jakupec, M.; Zorbas-Seifried, S.; Groessl, M.; Egger, A.; Berger, W.; Zorbas, H.; Dyson, P.; Keppler, B.K. KP1019, A New Redox-Active Anticancer Agent-Preclinical Development and Results of a Clinical Phase I Study in Tumor Patients. Chem. Biodivers. 2008, 5, 2140-2155. [CrossRef] [PubMed]

25. Pages, B.J.; Ang, D.L.; Wright, E.P.; Aldrich-Wright, J. Metal complex interactions with DNA. Dalton Trans. 2014, 44, 3505-3526. [CrossRef] [PubMed]

26. Ang, W.H.; Casini, A.; Sava, G.; Dyson, P.J. Organometallic ruthenium-based antitumor compounds with novel modes of action. J. Organomet. Chem. 2011, 696, 989-998. [CrossRef]

27. Renfrew, A.K.; Juillerat-Jeanneret, L.; Dyson, P.J. Adding diversity to ruthenium(II)-arene anticancer (RAPTA) compounds via click chemistry: The influence of hydrophobic chains. J. Organomet. Chem. 2011, 696, 772-779. [CrossRef]

28. Berndsen, R.H.; Weiss, A.; Abdul, U.K.; Wong, T.J.; Meraldi, P.; Griffioen, A.W.; Dyson, P.; Nowak-Sliwinska, P. Combination of ruthenium(II)-arene complex $\left[\mathrm{Ru}\left(\eta^{6}-\mathrm{p}\right.\right.$-cymene) $\mathrm{Cl}_{2}$ (pta) $]$ (RAPTA-C) and the epidermal growth factor receptor inhibitor erlotinib results in efficient angiostatic and antitumor activity. Sci. Rep. 2017, 7, srep43005. [CrossRef]

29. Nhukeaw, T.; Hongthong, K.; Dyson, P.J.; Ratanaphan, A. Cellular responses of BRCA1-defective HCC1937 breast cancer cells induced by the antimetastasis ruthenium(II) arene compound RAPTA-T. Apoptosis 2019, 24, 612-622. [CrossRef] 
30. Murray, B.; Babak, M.; Hartinger, C.; Dyson, P. The development of RAPTA compounds for the treatment of tumors. Coord. Chem. Rev. 2016, 306, 86-114. [CrossRef]

31. Peacock, A.; Habtemariam, A.; Fernández, R.; Walland, V.; Fabbiani, F.P.A.; Parsons, S.; Aird, R.E.; Jodrell, D.I.; Sadler, P.J. Tuning the Reactivity of Osmium(II) and Ruthenium(II) Arene Complexes under Physiological Conditions. J. Am. Chem. Soc. 2006, 128, 1739-1748. [CrossRef]

32. Peacock, A.; Sadler, P.J. Medicinal Organometallic Chemistry: Designing Metal Arene Complexes as Anticancer Agents. Chem.Asian J. 2008, 3, 1890-1899. [CrossRef]

33. Leijen, S.; Burgers, S.A.; Baas, P.; Pluim, D.; Tibben, M.; van Werkhoven, E.; Alessio, E.; Sava, G.; Beijnen, J.H.; Schellens, J.H.M. Phase I/II study with ruthenium compound NAMI-A and gemcitabine in patients with non-small cell lung cancer after first line therapy. Investig. New Drugs 2014, 33, 201-214. [CrossRef]

34. Monro, S.; Colón, K.L.; Yin, H.; Roque, J., III; Konda, P.; Gujar, S.; Thummel, R.P.; Lilge, L.; Cameron, C.G.; McFarland, S.A. Transition Metal Complexes and Photodynamic Therapy from a Tumor-Centered Approach: Challenges, Opportunities, and Highlights from the Development of TLD1433. Chem. Rev. 2019, 119, 797-828. [CrossRef]

35. Geldmacher, Y.; Splith, K.; Kitanovic, I.; Alborzinia, H.; Can, S.; Rubbiani, R.; Nazif, M.A.; Wefelmeier, P.; Prokop, A.; Ott, I.; et al. Cellular impact and selectivity of half-sandwich organorhodium(III) anticancer complexes and their organoiridium(III) and trichloridorhodium(III) counterparts. J. Biol. Inorg. Chem. 2012, 17, 631-646. [CrossRef]

36. Liu, Z.; Romero-Canelón, I.; Qamar, B.; Hearn, J.M.; Habtemariam, A.; Barry, N.P.E.; Pizarro, A.M.; Clarkson, G.J.; Sadler, P.J. The Potent Oxidant Anticancer Activity of Organoiridium Catalysts. Angew. Chem. Int. Ed. 2014, 53, 3941-3946. [CrossRef] [PubMed]

37. Ho, P.-Y.; Ho, C.-L.; Wong, W.-Y. Recent advances of iridium(III) metallophosphors for health-related applications. Coord. Chem. Rev. 2020, 413, 213267. [CrossRef]

38. Tensi, L.; Macchioni, A. Extremely Fast NADH-Regeneration Using Phosphonic Acid as Hydride Source and Iridium-pyridine-2sulfonamidate Catalysts. ACS Catal. 2020, 10, 7945-7949. [CrossRef]

39. Li, J.; Guo, L.; Tian, Z.; Tian, M.; Zhang, S.; Xu, K.; Qian, Y.; Liu, Z. Novel half-sandwich iridium(III) imino-pyridyl complexes showing remarkable in vitro anticancer activity. Dalton Trans. 2017, 46, 15520-15534. [CrossRef] [PubMed]

40. Xu, Z.; Kong, D.; He, X.; Guo, L.; Ge, X.; Liu, X.; Zhang, H.; Li, J.; Yang, Y.; Liu, Z. Mitochondria-targeted half-sandwich rutheniumII diimine complexes: Anticancer and antimetastasis via ROS-mediated signalling. Inorg. Chem. Front. 2018, 5, 2100-2105. [CrossRef]

41. Aird, R.E.; Cummings, J.; Ritchie, A.; Muir, M.; Morris, R.E.; Chen, H.; Sadler, P.J.; Jodrell, D.I. In vitro and in vivo activity and cross resistance profiles of novel ruthenium (II) organometallic arene complexes in human ovarian cancer. Br. J. Cancer 2002, 86, 1652-1657. [CrossRef]

42. Liu, Z.; Habtemariam, A.; Pizarro, A.M.; Fletcher, S.A.; Kisova, A.; Vrana, O.; Salassa, L.; Bruijnincx, P.; Clarkson, G.J.; Brabec, V.; et al. Organometallic Half-Sandwich Iridium Anticancer Complexes. J. Med. Chem. 2011, 54, 3011-3026. [CrossRef] [PubMed]

43. Yellol, J.G.; Pérez, S.A.; Buceta, A.; Yellol, G.S.; Donaire, A.; Szumlas, P.; Bednarski, P.J.; Makhloufi, G.; Janiak, C.; Espinosa, A.; et al. Novel C,N-Cyclometalated Benzimidazole Ruthenium(II) and Iridium(III) Complexes as Antitumor and Antiangiogenic Agents: A Structure-Activity Relationship Study. J. Med. Chem. 2015, 58, 7310-7327. [CrossRef] [PubMed]

44. Petruzzella, E.; Braude, J.P.; Aldrich-Wright, J.R.; Gandin, V.; Gibson, D. A Quadruple-Action Platinum(IV) Prodrug with Anticancer Activity Against KRAS Mutated Cancer Cell Lines. Angew. Chem. Int. Ed. 2017, 56, 11539-11544. [CrossRef] [PubMed]

45. Ott, I.; Kircher, B.; Bagowski, C.P.; Vlecken, D.H.W.; Ott, E.B.; Will, J.; Bensdorf, K.; Sheldrick, W.S.; Gust, R. Modulation of the Biological Properties of Aspirin by Formation of a Bioorganometallic Derivative. Angew. Chem. Int. Ed. 2009, 48, 1160-1163. [CrossRef] [PubMed]

46. Zimmermann, G.R.; Lehár, J.; Keith, C.T. Multi-target therapeutics: When the whole is greater than the sum of the parts. Drug Discov. Today 2007, 12, 34-42. [CrossRef] [PubMed]

47. Patel, R.V.; Mistry, B.; Syed, R.; Rathi, A.K.; Lee, Y.-J.; Sung, J.-S.; Shinf, H.-S.; Keum, Y.-S. Chrysin-piperazine conjugates as antioxidant and anticancer agents. Eur. J. Pharm. Sci. 2016, 88, 166-177. [CrossRef] [PubMed]

48. Lemanska, K.; Szymusiak, H.; Tyrakowska, B.; Zielinski, R.; Soffers, A.E.; Rietjens, I.M.C.M. The influence of pH on antioxidant properties and the mechanism of antioxidant action of hydroxyflavones. Free Radic. Biol. Med. 2001, 31, 869-881. [CrossRef]

49. Pietta, P.-G. Flavonoids as Antioxidants. J. Nat. Prod. 2000, 63, 1035-1042. [CrossRef]

50. Cushnie, T.T.; Lamb, A.J. Antimicrobial activity of flavonoids. Int. J. Antimicrob. Agents 2005, 26, 343-356. [CrossRef]

51. Harborne, J.B.; Williams, C.A. Advances in flavonoid research since 1992. Phytochemistry 2000, 55, 481-504. [CrossRef]

52. Middleton, E.; Kandaswami, C.; Theoharides, T.C. The effects of plant flavonoids on mammalian cells: Implications for inflammation, heart disease, and cancer. Pharmacol. Rev. 2000, 4, 52.

53. Galati, G.; O'Brien, P.J. Potential toxicity of flavonoids and other dietary phenolics: Significance for their chemopreventive and anticancer properties. Free Radic. Biol. Med. 2004, 37, 287-303. [CrossRef]

54. Williams, R.J.; Spencer, J.P.; Rice-Evans, C. Flavonoids: Antioxidants or signalling molecules? Free Radic. Biol. Med. 2004, 36, 838-849. [CrossRef] [PubMed]

55. Rusak, G.; Piantanida, I.; Mašić, L.; Kapuralin, K.; Durgo, K.; Kopjar, N. Spectrophotometric analysis of flavonoid-DNA interactions and DNA damaging/protecting and cytotoxic potential of flavonoids in human peripheral blood lymphocytes. Chem. Interact. 2010, 188, 181-189. [CrossRef] [PubMed] 
56. Grazul, M.; Budzisz, E. Biological activity of metal ions complexes of chromones, coumarins and flavones. Coord. Chem. Rev. 2009, 253, 2588-2598. [CrossRef]

57. Małecka, M.; Skoczyńska, A.; Goodman, D.M.; Hartinger, C.G.; Budzisz, E. Biological properties of ruthenium(II)/(III) complexes with flavonoids as ligands. Coord. Chem. Rev. 2021, 436, 213849. [CrossRef]

58. Dolatabadi, J.E.N. Molecular aspects on the interaction of quercetin and its metal complexes with DNA. Int. J. Biol. Macromol. 2011, 48, 227-233. [CrossRef]

59. Gaur, R.; Mishra, L. Bi-nuclear Ru(II) complexes of bis-chalcone and bis-flavonol: Synthesis, characterization, photo cleavage of DNA and Topoisomerase I inhibition. RSC Adv. 2013, 3, 12210-12219. [CrossRef]

60. Marques, J.; Silva, A.M.; Marques, M.P.M.; Braga, S.S. Ruthenium(II) trithiacyclononane complexes of 7,3', $4^{\prime}$-trihydroxyflavone, chrysin and tectochrysin: Synthesis, characterisation, and cytotoxic evaluation. Inorg. Chim. Acta 2019, 488, 71-79. [CrossRef]

61. Wang, Y.; Bian, L.; Chakraborty, T.; Ghosh, T.; Chanda, P.; Roy, S. Construing the Biochemical and Molecular Mechanism Underlying the In Vivo and In Vitro Chemotherapeutic Efficacy of Ruthenium-Baicalein Complex in Colon Cancer. Int. J. Biol. Sci. 2019, 15, 1052-1071. [CrossRef]

62. Thangavel, P.; Viswanath, B.; Kim, S. Synthesis and characterization of kaempferol-based ruthenium (II) complex: A facile approach for superior anticancer application. Mater. Sci. Eng. C 2018, 89, 87-94. [CrossRef] [PubMed]

63. Roy, S.; Das, R.; Ghosh, B.; Chakraborty, T. Deciphering the biochemical and molecular mechanism underlying the in vitro and in vivo chemotherapeutic efficacy of ruthenium quercetin complex in colon cancer. Mol. Carcinog. 2018, 57, 700-721. [CrossRef] [PubMed]

64. Kasprzak, M.; Fabijańska, M.; Chęcińska, L.; Studzian, K.; Markowicz-Piasecka, M.; Sikora, J.; Mikiciuk-Olasik, E.; Ochocki, J. Small differences in structure, a large difference in activity-Comparing a new Ru(II)-3-hydroxyiminoflavanone complex with analogous $\mathrm{Ru}(\mathrm{II})$ compounds. Inorg. Chim. Acta 2017, 457, 69-80. [CrossRef]

65. Garcia, J.P.; Lakshmi, B.A.; Kim, S. Potential anticancer applications of the novel naringin-based ruthenium (II) complex. 3 Biotech 2019, 9, 181. [CrossRef] [PubMed]

66. Lakshmi, B.A.; Bae, J.-Y.; An, J.H.; Kim, S. Facile design and spectroscopic characterization of novel bio-inspired Quercetinconjugated tetrakis (dimethylsulfoxide)dichlororuthenium(II) complex for enhanced anticancer properties. Inorg. Chim. Acta 2019, 495, 118989. [CrossRef]

67. Medina, J.J.M.; Naso, L.G.; Pérez, A.L.; Rizzi, A.; Okulik, N.B.; Ferrer, E.G.; Williams, P.A. Apigenin oxidovanadium(IV) cation interactions. Synthesis, spectral, bovine serum albumin binding, antioxidant and anticancer studies. J. Photochem. Photobiol. A Chem. 2017, 344, 84-100. [CrossRef]

68. Naso, L.G.; Lezama, L.; Valcarcel, M.; Salado, C.; Villacé, P.; Kortazar, D.; Ferrer, E.G.; Williams, P.A. Bovine serum albumin binding, antioxidant and anticancer properties of an oxidovanadium(IV) complex with luteolin. J. Inorg. Biochem. 2016, 157, 80-93. [CrossRef] [PubMed]

69. Tu, L.-Y.; Pi, J.; Jin, H.; Cai, J.-Y.; Deng, S.-P. Synthesis, characterization and anticancer activity of kaempferol-zinc(II) complex. Bioorganic Med. Chem. Lett. 2016, 26, 2730-2734. [CrossRef]

70. Roy, A.S.; Tripathy, D.R.; Samanta, S.; Ghosh, S.K.; Dasgupta, S. DNA damaging, cell cytotoxicity and serum albumin binding efficacy of the rutin-Cu(II) complex. Mol. BioSyst. 2016, 12, 1687-1701. [CrossRef]

71. Qian, J.-Z.; Wang, B.C.; Fan, Y.; Tan, J.; Yang, X. QSAR study of flavonoid-metal complexes and their anticancer activities. J. Struct. Chem. 2015, 56, 338-345. [CrossRef]

72. De Souza, R.F.V.; De Giovani, W.F. Antioxidant properties of complexes of flavonoids with metal ions. Redox Rep. 2004, 9, 97-104. [CrossRef] [PubMed]

73. Zeng, Y.-B.; Yang, N.; Liu, W.-S.; Tang, N. Synthesis, characterization and DNA-binding properties of La(III) complex of chrysin. J. Inorg. Biochem. 2003, 97, 258-264. [CrossRef]

74. Schmidlehner, M.; Flocke, L.S.; Roller, A.; Hejl, M.; Jakupec, M.A.; Kandioller, W.; Keppler, B.K. Cytotoxicity and preliminary mode of action studies of novel 2-aryl-4-thiopyrone-based organometallics. Dalton Trans. 2015, 45, 724-733. [CrossRef]

75. Kurzwernhart, A.; Mokesch, S.; Klapproth, E.; Adib-Ravazi, M.S.; Jakupec, M.A.; Hartinger, C.G.; Kandioller, W.; Keppler, B.K. Flavonoid-Based Organometallics with Different Metal Centers-Investigations of the Effects on Reactivity and Cytotoxicity. Eur. J. Inorg. Chem. 2015, 2016, 240-246. [CrossRef]

76. Kurzwernhart, A.; Kandioller, W.; Bächler, S.; Bartel, C.; Martic, S.; Buczkowska, M.; Mühlgassner, G.; Jakupec, M.A.; Kraatz, H.-B.; Bednarski, P.J.; et al. Structure-Activity Relationships of Targeted RuII( $\eta^{6}$-p-Cymene) Anticancer Complexes with Flavonol-Derived Ligands. J. Med. Chem. 2012, 55, 10512-10522. [CrossRef] [PubMed]

77. Kurzwernhart, A.; Kandioller, W.; Bartel, C.; Bächler, S.; Trondl, R.; Mühlgassner, G.; Jakupec, M.A.; Arion, V.B.; Marko, D.; Keppler, B.K.; et al. Targeting the DNA-topoisomerase complex in a double-strike approach with a topoisomerase inhibiting moiety and covalent DNA binder. Chem. Commun. 2012, 48, 4839-4841. [CrossRef] [PubMed]

78. Schwarz, M.B.; Kurzwernhart, A.; Roller, A.; Kandioller, W.; Keppler, B.K.; Hartinger, C.G. Rhodium(Cp*) Compounds with Flavone-derived Ligand Systems: Synthesis and Characterization. Z. Anorg. Allg. Chem. 2013, 639, 1648-1654. [CrossRef]

79. Tabrizi, L.; Nguyen, T.L.A.; Dao, D.Q. Experimental and theoretical investigation of cyclometalated phenylpyridine iridium(iii) complex based on flavonol and ibuprofen ligands as potent antioxidant. RSC Adv. 2019, 9, 17220-17237. [CrossRef]

80. Kasprzak, M.M.; Erxleben, A.; Ochocki, J. Properties and applications of flavonoid metal complexes. RSC Adv. 2015, 5, 4585345877. [CrossRef] 
81. Mercer, L.D.; Kelly, B.L.; Horne, M.K.; Beart, P.M. Dietary polyphenols protect dopamine neurons from oxidative insults and apoptosis: Investigations in primary rat mesencephalic cultures. Biochem. Pharmacol. 2005, 69, 339-345. [CrossRef]

82. Gresa-Arribas, N.; Serratosa, J.; Saura, J.; Solà, C. Inhibition of CCAAT/enhancer binding protein $\delta$ expression by chrysin in microglial cells results in anti-inflammatory and neuroprotective effects. J. Neurochem. 2010, 115, 526-536. [CrossRef]

83. Mansour, S.Z.; Moawed, F.S.; Elmarkaby, S.M. Protective effect of 5, 7-dihydroxyflavone on brain of rats exposed to acrylamide or $\gamma$-radiation. J. Photochem. Photobiol. B Biol. 2017, 175, 149-155. [CrossRef]

84. Phan, T.; Yu, X.-M.; Kunnimalaiyaan, M.; Chen, H. Antiproliferative Effect of Chrysin on Anaplastic Thyroid Cancer. J. Surg. Res. 2011, 170, 84-88. [CrossRef] [PubMed]

85. Zahirović, A.; Kahrović, E.; Cindrić, M.; Pavelić, S.K.; Hukić, M.; Harej, A.; Turkušić, E. Heteroleptic ruthenium bioflavonoid complexes: From synthesis to in vitro biological activity. J. Coord. Chem. 2017, 70, 4030-4053. [CrossRef]

86. Munteanu, A.-C.; Notaro, A.; Jakubaszek, M.; Cowell, J.; Tharaud, M.; Goud, B.; Uivarosi, V.; Gasser, G. Synthesis, Characterization, Cytotoxic Activity, and Metabolic Studies of Ruthenium(II) Polypyridyl Complexes Containing Flavonoid Ligands. Inorg. Chem. 2020, 59, 4424-4434. [CrossRef]

87. Roy, S.; Sil, A.; Chakraborty, T. Potentiating apoptosis and modulation of p53, Bcl2, and Bax by a novel chrysin ruthenium complex for effective chemotherapeutic efficacy against breast cancer. J. Cell. Physiol. 2018, 234, 4888-4909. [CrossRef] [PubMed]

88. Ravishankar, D.; Salamah, M.; Attina, A.; Pothi, R.; Vallance, T.; Javed, M.; Williams, H.F.; Alzahrani, E.M.S.; Kabova, E.; Vaiyapuri, R.; et al. Ruthenium-conjugated chrysin analogues modulate platelet activity, thrombus formation and haemostasis with enhanced efficacy. Sci. Rep. 2017, 7, 1-16. [CrossRef] [PubMed]

89. Yadav, S.; Singh, J.D. Synthesis and preliminary biological evaluation for the anticancer activity of organochalcogen (S/Se) tethered chrysin based organometallic RuII(n6-p-cymene) complexes. J. Biomol. Struct. Dyn. 2019, 37, 3337-3353. [CrossRef] [PubMed]

90. Fu, W.; Wang, J.; Yu, L.; Zhao, L.; Lu, N.; You, Q.; Guo, Q.; Li, Z. Synthesis and biological evaluation of 7-O-modified oroxylin A derivatives. Bioorganic Med. Chem. Lett. 2012, 22, 1118-1121. [CrossRef] [PubMed]

91. Hu, K.; Wang, W.; Cheng, H.; Pan, S.; Ren, J. Synthesis and cytotoxicity of novel chrysin derivatives. Med. Chem. Res. 2010, 20, 838-846. [CrossRef]

92. Shin, J.-S.; Kim, K.-S.; Kim, M.-B.; Jeong, J.-H.; Kim, B.-K. Synthesis and hypoglycemic effect of chrysin derivatives. Bioorganic Med. Chem. Lett. 1999, 9, 869-874. [CrossRef]

93. Cheng, N.; Yi, W.-B.; Wang, Q.-Q.; Peng, S.-M.; Zou, X.-Q. Synthesis and $\alpha$-glucosidase inhibitory activity of chrysin, diosmetin, apigenin, and luteolin derivatives. Chin. Chem. Lett. 2014, 25, 1094-1098. [CrossRef]

94. Mistry, B.M.; Patel, R.V.; Keum, Y.-S.; Kim, D.H. Chrysin-benzothiazole conjugates as antioxidant and anticancer agents. Bioorganic Med. Chem. Lett. 2015, 25, 5561-5565. [CrossRef] [PubMed]

95. Babu, K.S.; Babu, T.H.; Srinivas, P.; Kishore, K.H.; Murthy, U.; Rao, J.M. Synthesis and biological evaluation of novel C (7) modified chrysin analogues as antibacterial agents. Bioorganic Med. Chem. Lett. 2006, 16, 221-224. [CrossRef] [PubMed]

96. Zou, X.-Q.; Peng, S.-M.; Hu, C.-P.; Tan, L.-F.; Yuan, Q.; Deng, H.-W.; Li, Y.-J. Synthesis, characterization and vasculoprotective effects of nitric oxide-donating derivatives of chrysin. Bioorganic Med. Chem. 2010, 18, 3020-3025. [CrossRef]

97. Lapkin, A.; Adou, E.; Mlambo, B.N.; Chemat, S.; Suberu, J.; Collis, A.E.; Clark, A.; Barker, G. Integrating medicinal plants extraction into a high-value biorefinery: An example of Artemisia annua L. C. R. Chim. 2014, 17, 232-241. [CrossRef]

98. Valdez-Calderón, A.; González-Montiel, S.; Martínez-Otero, D.; Martínez-Torres, A.; Vásquez-Pérez, J.M.; Molina-Vera, C.; Torres-Valencia, J.M.; Alvarado-Rodríguez, J.G.; Cruz-Borbolla, J. Synthesis, structural study and biological activity of new derivatives of chrysin containing a 2-mercaptopyridyl or 5-(trifluoromethyl)-2-mercaptopyridyl fragments. J. Mol. Struct. 2016, 1110, 196-207. [CrossRef]

99. Zelonka, M.C.; Baird, R.A. Benzene Complexes of Ruthenium(II). Can. J. Chem. 1972, 50, 3063-3072. [CrossRef]

100. Bennett, M.A.; Smith, A.K. Arene ruthenium(II) complexes formed by dehydrogenation of cyclohexadienes with ruthenium(III) trichloride. J. Chem. Soc. Dalton Trans. 1974, 233-241. [CrossRef]

101. White, C.; Yates, A.; Maitlis, P.M. (eta5-pentamethylcyclopentadienyl)-rhodium and -iridium compounds. Inorg. Synth. 1992, 29, 228-234.

102. Bruker. SAINT v8.37, APEX3 v2016.1.0; Bruker AXS: Madison, WI, USA, 2016.

103. Krause, L.; Herbst-Irmer, R.; Sheldrick, G.M.; Stalke, D. SADABS. J. Appl. Crystallogr. 2015, 48, 3. [CrossRef] [PubMed]

104. Farrugia, L.J. WinGXandORTEP for Windows: An update. J. Appl. Crystallogr. 2012, 45, 849-854. [CrossRef]

105. Sheldrick, G.M. SHELX-2014, Program for Crystal Structure Refinement; University of Göttingen: Göttingen, Germany, 2014.

106. Zanda, E.; Busto, N.; Biancalana, L.; Zacchini, S.; Biver, T.; Garcia, B.; Marchetti, F. Anticancer and antibacterial potential of robust Ruthenium(II) arene complexes regulated by choice of $\alpha$-diimine and halide ligands. Chem. Interact. 2021, 344, 109522. [CrossRef] [PubMed]

107. Park, Y.; Moon, B.-H.; Lee, E.; Lee, Y.; Yoon, Y.; Ahn, J.-H.; Lim, Y. ${ }^{1} \mathrm{H}$ and ${ }^{13}$ C-NMR data of hydroxyflavone derivatives. Magn. Reson. Chem. 2007, 45, 674-679. [CrossRef]

108. Nguyen, T.K.P.; Nguyen, K.P.P.; Kamounah, F.S.; Zhang, W.; Hansen, P.E. NMR of a series of novel hydroxyflavothiones. Magn. Reson. Chem. 2009, 47, 1043-1054. [CrossRef]

109. Uivarosi, V.; Badea, M.; Olar, R.; Drăghici, C.; Bărbuceanu, F. Synthesis and Characterization of Some New Complexes of Magnesium (II) and Zinc (II) with the Natural Flavonoid Primuletin. Molecules 2013, 18, 7631-7645. [CrossRef] 
110. Parveen, S.; Hanif, M.; Movassaghi, S.; Sullivan, M.P.; Kubanik, M.; Shaheen, M.A.; Söhnel, T.; Jamieson, S.M.F.; Hartinger, C.G.

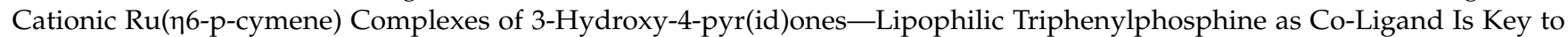
Highly Stable and Cytotoxic Anticancer Agents. Eur. J. Inorg. Chem. 2016, 2017, 1721-1727. [CrossRef]

111. Biancalana, L.; Pampaloni, G.; Zacchini, S.; Marchetti, F. Synthesis, characterization and behavior in water/DMSO solution of $\mathrm{Ru}(\mathrm{II})$ arene complexes with bioactive carboxylates. J. Organomet. Chem. 2018, 869, 201-211. [CrossRef]

112. Patra, M.; Joshi, T.; Pierroz, V.; Ingram, K.; Kaiser, M.; Ferrari, P.-D.D.S.; Spingler, P.-D.D.B.; Keiser, J.; Gasser, G. DMSO-Mediated Ligand Dissociation: Renaissance for Biological Activity of $\mathrm{N}-H e t e r o c y c l i c-\left[\mathrm{Ru}\left(\eta^{6}\right.\right.$-arene $\left.) \mathrm{Cl}_{2}\right]$ Drug Candidates. Chem. A Eur. J. 2013, 19, 14768-14772. [CrossRef]

113. Dömötör, O.; Aicher, S.; Schmidlehner, M.; Novak, M.S.; Roller, A.; Jakupec, M.; Kandioller, W.; Hartinger, C.; Keppler, B.; Enyedy, A. Antitumor pentamethylcyclopentadienyl rhodium complexes of maltol and allomaltol: Synthesis, solution speciation and bioactivity. J. Inorg. Biochem. 2014, 134, 57-65. [CrossRef] [PubMed]

114. Eisen, M.S.; Haskel, A.; Chen, H.; Olmstead, M.M.; Smith, D.P.; Maestre, M.F.; Fish, R.H. Aqueous Organometallic Chemistry:

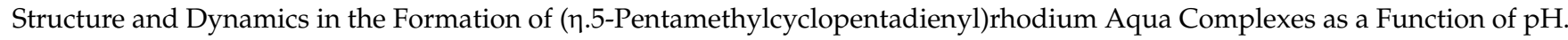
Organometallics 1995, 14, 2806-2812. [CrossRef]

115. Ogo, S.; Makihara, N.; Watanabe, Y. pH-dependent transfer hydrogenation of water-soluble carbonyl compounds with $\left[\mathrm{Cp}^{*} \operatorname{Ir}{ }^{\mathrm{III}}\left(\mathrm{H}_{2} \mathrm{O}\right)_{3}\right]^{2+}\left(\mathrm{Cp}^{*}=\eta^{5} \mathrm{C}_{5} \mathrm{Me}_{5}\right)$ as a catalyst precursor and $\mathrm{HCOONa}$ as a hydrogen donor in water. Organometallics 1999, 18, 5470-5474. [CrossRef]

116. Kandioller, W.; Hartinger, C.G.; Nazarov, A.A.; Bartel, C.; Skocic, M.; Jakupec, M.; Arion, V.B.; Keppler, B. Maltol-Derived Ruthenium-Cymene Complexes with Tumor Inhibiting Properties: The Impact of Ligand-Metal Bond Stability on Anticancer Activity In Vitro. Chem. A Eur. J. 2009, 15, 12283-12291. [CrossRef] [PubMed]

117. Turel, I.; Kljun, J.; Perdih, F.; Morozova, E.; Bakulev, V.; Kasyanenko, N.; Byl, J.A.W.; Osheroff, N. First Ruthenium Organometallic Complex of Antibacterial Agent Ofloxacin. Crystal Structure and Interactions with DNA. Inorg. Chem. 2010, 49, 10750-10752. [CrossRef] [PubMed]

118. Peacock, A.; Melchart, M.; Deeth, R.; Habtemariam, A.; Parsons, S.; Sadler, P.J. Osmium(II) and Ruthenium(II) Arene Maltolato Complexes: Rapid Hydrolysis and Nucleobase Binding. Chem. A Eur. J. 2007, 13, 2601-2613. [CrossRef]

119. Bíró, L.; Farkas, E.; Buglyó, P. Hydrolytic behaviour and chloride ion binding capability of $\left[\mathrm{Ru}\left(\eta^{6}-\mathrm{p}-\mathrm{cym}\right)\left(\mathrm{H}_{2} \mathrm{O}\right)_{3}\right]^{2+}: \mathrm{A}$ solution equilibrium study. Dalton Trans. 2012, 41, 285-291. [CrossRef]

120. Nutton, A.; Bailey, P.M.; Maitlis, P.M. Pentamethylcyclopentadienyl-rhodium and -iridium Complexes. Part 29. Syntheses

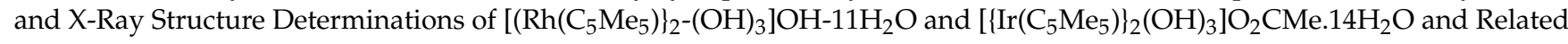
Complexes. J. Chem. Soc. Dalton Trans. 1981, 9, 1997-2002. [CrossRef]

121. Po, H.N.; Senozan, N.M. The Henderson-Hasselbalch Equation: Its History and Limitations. J. Chem. Educ. 2001, 78, 1499-1503. [CrossRef]

122. Ang, K.-P. A Spectrophotometric Method for the Determination of Overlapping Ionization Constants. J. Phys. Chem. 1958, 62, 1109-1112. [CrossRef]

123. Castro, G.; Ferretti, F.; Blanco, S. Determination of the overlapping pKa values of chrysin using UV-vis spectroscopy and ab initio methods. Spectrochim. Acta Part A Mol. Biomol. Spectrosc. 2005, 62, 657-665. [CrossRef] [PubMed]

124. Um, I.-H.; Lee, E.-J.; Jeon, S.-E. Effect of solvent on reactivity and basicity: Aminolyses of p-nitrophenyl acetate in $\mathrm{H}_{2} \mathrm{O}$ and in DMSO. J. Phys. Org. Chem. 2002, 15, 561-565. [CrossRef]

125. Martinez-Alonso, M.; Busto, N.; Jalon, F.A.; Manzano, B.R.; Leal, J.M.; Rodriguez, A.M.; Garcia, B.; Espino, G. Derivation of Structure-Activity Relationships from the Anticancer Properties of Ruthenium(II) Arene Complexes with 2-Aryldiazole Ligands. Inorg. Chem. 2014, 53, 11274-11288. [CrossRef] [PubMed]

126. Mészáros, J.P.; Dömötör, O.; Hackl, C.M.; Roller, A.; Keppler, B.K.; Kandioller, W.; Enyedy, E.A.A. Structural and solution equilibrium studies on half-sandwich organorhodium complexes of $(\mathrm{N}, \mathrm{N})$ donor bidentate ligands. New J. Chem. 2018, 42, 11174-11184. [CrossRef]

127. Dehkhodaei, M.; Sahihi, M.; Rudbari, H.A.; Momenbeik, F. DNA and HSA interaction of Vanadium (IV), Copper (II), and Zinc (II) complexes derived from an asymmetric bidentate Schiff-base ligand: Multi spectroscopic, viscosity measurements, molecular docking, and ONIOM studies. J. Biol. Inorg. Chem. 2017, 23, 181-192. [CrossRef]

128. Liu, H.-K.; Sadler, P.J. Metal Complexes as DNA Intercalators. Accounts Chem. Res. 2011, 44, 349-359. [CrossRef]

129. Rubio-Antolin, A.R. Interacción de ARN Con Doxorrubicina: Influencia del Ligando y del Metal en la Actividad Biológica de Complejos Organometálicos. Ph.D. Thesis, University of Burgos, Burgos, Spain, 2020. [CrossRef]

130. Neissa, J.; Pérez-Arnaiz, C.; Porto, V.; Busto, N.; Borrajo, E.; Leal, J.M.; López-Quintela, M.A.; García, B.; Dominguez, F. Interaction of silver atomic quantum clusters with living organisms: Bactericidal effect of $\mathrm{Ag}_{3}$ clusters mediated by disruption of topoisomerase-DNA complexes. Chem. Sci. 2015, 6, 6717-6724. [CrossRef]

131. Moreira, J.D.V.; Schwartz, L.; Jolicoeur, M. Targeting Mitochondrial Singlet Oxygen Dynamics Offers New Perspectives for Effective Metabolic Therapies of Cancer. Front. Oncol. 2020, 10, 573399. [CrossRef] [PubMed]

132. Habas, K.; Soldevila-Barreda, J.J.; Azmanova, M.; Rafols, L.; Pitto-Barry, A.; Anderson, D.; Barry, N.P.E. Evaluation of the Toxicity of Two Electron-Deficient Half-Sandwich Complexes against Human Lymphocytes from Healthy Individuals. ChemMedChem 2021, 16, 624-629. [CrossRef] 
133. Li, J.; Tian, Z.; Xu, Z.; Zhang, S.; Feng, Y.; Zhang, L.; Liu, Z. Highly potent half-sandwich iridium and ruthenium complexes as lysosome-targeted imaging and anticancer agents. Dalton Trans. 2018, 47, 15772-15782. [CrossRef]

134. Xu, Z.; Zhang, Y.; Zhang, S.; Jia, X.; Zhong, G.; Yang, Y.; Du, Q.; Li, J.; Liu, Z. Novel half-sandwich iridium O^C (carbene)Complexes: In vitro and in vivo tumor growth suppression and pro-apoptosis via ROS-mediated cross-talk between mitochondria and lysosomes. Cancer Lett. 2019, 447, 75-85. [CrossRef] [PubMed]

135. Rhee, S.G.; Chang, T.-S.; Jeong, W.; Kang, D. Methods for detection and measurement of hydrogen peroxide inside and outside of cells. Mol. Cells 2010, 29, 539-549. [CrossRef] [PubMed]

136. Li, J.; Tian, Z.; Ge, X.; Xu, Z.; Feng, Y.; Liu, Z. Design, synthesis, and evaluation of fluorine and Naphthyridine-Based halfsandwich organoiridium/ruthenium complexes with bioimaging and anticancer activity. Eur. J. Med. Chem. 2019, 163, 830-839. [CrossRef]

137. Chen, C.; Xu, C.; Li, T.; Lu, S.; Luo, F.; Wang, H. Novel NHC-coordinated ruthenium(II) arene complexes achieve synergistic efficacy as safe and effective anticancer therapeutics. Eur. J. Med. Chem. 2020, 203, 112605. [CrossRef]

138. Sullivan, M.P.; Holtkamp, H.U.; Hartinger, C.G. Antitumor Metallodrugs that Target Proteins. Met.-Drugs Dev. Action Anticancer Agents 2018, 18, 351-386.

139. Pérez-Arnaiz, C.; Leal, J.; Busto, N.; Carrión, M.C.; Rubio, A.R.; Ortiz, I.; Barone, G.; de Greñu, B.D.; Santolaya, J.; Leal, J.M.; et al. Role of Seroalbumin in the Cytotoxicity of cis-Dichloro Pt(II) Complexes with (N^N)-Donor Ligands Bearing Functionalized Tails. Inorg. Chem. 2018, 57, 6124-6134. [CrossRef] 